\title{
Dispersion and Intersection of Hydrothermal Plumes in the Manus Back-Arc Basin, Western Pacific
}

\author{
Zhigang Zeng $\mathbb{D},{ }^{1,2,3,4}$ Xiaoyuan Wang $\mathbb{D}^{1,2}$ Bramley J. Murton, ${ }^{5}$ Haiyan Qi, ${ }^{1}$ \\ Berit Lehrmann, ${ }^{5}$ Xiaohui Li, ${ }^{1}$ Zuxing Chen, ${ }^{1}$ and Yunchao Shu ${ }^{6}$ \\ ${ }^{1}$ Seafloor Hydrothermal Activity Laboratory, CAS Key Laboratory of Marine Geology and Environment, Institute of Oceanology, \\ Chinese Academy of Sciences, Qingdao 266071, China \\ ${ }^{2}$ Laboratory for Marine Mineral Resources, Qingdao National Laboratory for Marine Science and Technology, \\ Qingdao 266071, China \\ ${ }^{3}$ University of Chinese Academy of Sciences, Beijing 100049, China \\ ${ }^{4}$ Center for Ocean Mega-Science, Chinese Academy of Sciences, 7 Nanhai Road, Qingdao 266071, China \\ ${ }^{5}$ National Oceanography Centre, European Way, Southampton SO14 3ZH, UK \\ ${ }^{6}$ Department of Geology and Geophysics, Woods Hole Oceanographic Institution, Woods Hole, MA 02543, USA
}

Correspondence should be addressed to Zhigang Zeng; zgzeng@ms.qdio.ac.cn and Xiaoyuan Wang; wangxiaoyuan@qdio.ac.cn

Received 27 October 2019; Revised 21 December 2019; Accepted 13 January 2020; Published 15 February 2020

Academic Editor: Marcello Liotta

Copyright ( 2020 Zhigang Zeng et al. This is an open access article distributed under the Creative Commons Attribution License, which permits unrestricted use, distribution, and reproduction in any medium, provided the original work is properly cited.

\begin{abstract}
The composition of hydrothermal plumes reflects the physical and chemical characteristics of seafloor hydrothermal fluids, which in turn reflects the host rock and subseafloor reaction conditions as well as the water column processes that act to alter the plumes as they disperse and age. Here, we show that the turbidity, current, $\mathrm{pH}$ value, dissolved $\mathrm{Fe}(\mathrm{dFe})$, and dissolved $\mathrm{Mn}(\mathrm{dMn})$ compositions of hydrothermal plumes can be used to understand the spatial distribution and source of hydrothermal systems in the submarine geological environment. Data were obtained from 18 hydrocast stations, among which the water column samples were collected at 8 stations during the MANUS cruise of R/V KEXUE in 2015. The results showed that the Satanic Mills plume and Fenway plume rose approximately $140 \mathrm{~m}$ and $220 \mathrm{~m}$ above the seafloor, respectively. In the Satanic Mills plume, dFe remained longer than $\mathrm{dMn}$ during lateral plume dispersal. There was a clear intersection of the Satanic Mills plume and Fenway plume between $1625 \mathrm{~m}$ and $1550 \mathrm{~m}$ in the PACMANUS hydrothermal field, and the varied dispersion trends of the mixed plumes were affected by current velocities at different depths. The physical and chemical properties of the seawater columns in the Manus Basin were affected by the input of high-Mn, high-Fe, and low-Mg vent fluids. The turbidity and $\mathrm{dFe}$, dMn, and dissolved Mg concentrations in the sections of the plumes proximal to the Satanic Mills, Fenway, and Desmos vent sites were generally higher (turbidity, $\mathrm{Mn}$, and $\mathrm{Fe}$ ) and lower $(\mathrm{Mg}$ ) than those in the sections of the plumes that were more distal from the vent sites. This implied that the plumes proximal to their vent fluid sources, which were interpreted to have relatively young ages, dispersed chemically over time, and their concentrations became more similar to those of the plumes that were more distal from their vent fluid sources.
\end{abstract}

\section{Introduction}

Hydrothermal plumes represent a significant dispersal mechanism for chemicals released from seafloor vents to the oceans. They are also of interest to geochemists because they can be exploited to detect and locate new hydrothermal fields [1]. Hydrothermal circulation in young oceanic crust involves cold seawater that penetrates the seafloor and reacts with the underlying rocks, where it undergoes chemical and thermal modification and is converted into hydrothermal fluid enriched in dissolved $\mathrm{Fe}(\mathrm{dFe})$ and dissolved $\mathrm{Mn}$ $(\mathrm{dMn})$ that is often one million times more concentrated than the background deep ocean concentrations [1-4]. As soon as they emerge at seafloor hydrothermal vents, the fluids begin the processes of mixing and chemical exchange with ambient seawater and oxidation, dispersion, and settling 


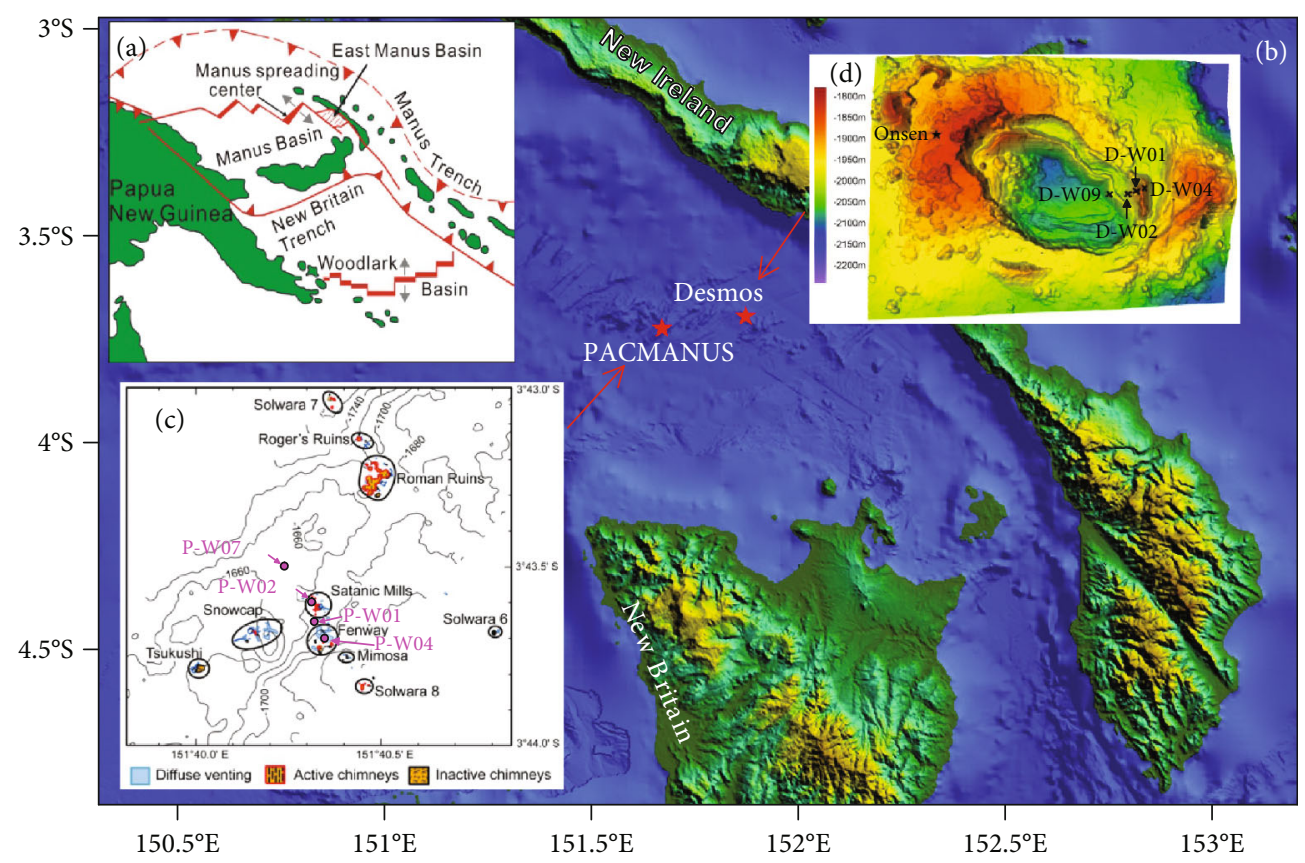

Figure 1: (a) Tectonic map of the Manus Basin (modified from Binns et al. 1995). (b) Location of hydrothermal fields in the eastern Manus back-arc basin (bathymetric map and data were obtained from http://www.geomapapp.org/index.htm). (c) Location of CTD stations in the Satanic Mills and Fenway vent sites in the PACMANUS hydrothermal field (modified from [34]). (d) Location of CTD stations in the Desmos hydrothermal field (modified from [44]).

of particles by physical processes [1, 5-11]. The resulting hydrothermal plumes can be traced over tens to thousands of kilometers using tracers, such as $\mathrm{dMn}, \mathrm{dFe}$, particulates, and isotopes such as ${ }^{3} \mathrm{He}[12,13]$. Total $\mathrm{dFe}$ is expected to rapidly precipitate from hydrothermal plumes in solid phases as sulfides or oxyhydroxides [11, 14]. Moreover, the long-distance transport of hydrothermally sourced $\mathrm{dFe}$ has been identified in the Pacific Ocean [15]. The stabilization mechanisms for $\mathrm{dFe}$ include the formation of small inorganic nanoparticles in the colloidal size fraction [16-18], complexation by organic ligands [19-21], and reversibility of exchange onto slowly sinking particles [12] that protect $\mathrm{dFe}$ from precipitation and gravitational settling. By contrast, the dMn within hydrothermal plumes typically exhibits much slower oxidation kinetics and remains predominantly in dissolved form at the time of emplacement in the nonbuoyant plume [1]. As such, the plumes carry with them a record of the source fluids, reaction conditions below the seafloor, and thermal energy fluxes produced at the vents. However, the plumes proximal to their vent fluid sources are formed later and are younger than those far from their vent fluid sources.

Since 1990, studies on seafloor hydrothermal activities in the eastern Manus back-arc basin have shown widespread occurrence of hydrothermal plumes. For example, during the 21st cruise of R/V Akademik Mstislav Keldysh, all seawater column casts in the Manus Basin showed elevated turbidity anomalies (up to 1880 nephels at a depth of $1600 \mathrm{~m}$ ) and positive anomalies of $\mathrm{dMn}$ (up to $43.5 \mathrm{nmol} / \mathrm{kg}$ at a depth of 1975 m) [22]. Later, during November and December of that year, large-scale triple-layered buoyant plumes were identified from water column anomalies of dMn (up to $97 \mathrm{nmol} / \mathrm{kg}$ at a depth of $1732 \mathrm{~m}$ ) and $\mathrm{pH}$ (as low as 7.55 at a depth of $1700 \mathrm{~m}$ ) in the eastern Manus Basin [23]. Furthermore, during the KX08-973 cruise of R/V KEXUE YIHAO in 2008, buoyant plumes were identified at $1.8 \mathrm{~km}$ north-northwest of the Desmos caldera (dMn of up to $79.3 \mathrm{nM}$ at a depth of $1641 \mathrm{~m}$ ), above the North Susu Knolls (dMn of up to $36.3 \mathrm{nM}$ at a depth of $1492 \mathrm{~m}$ ), and $1.3 \mathrm{~km}$ to the east of the Suzette hydrothermal field (dMn of up to $110.8 \mathrm{nM}$ at a depth of $1500 \mathrm{~m}$ ) [24].

Despite the progress made by these studies, little is known about the influence of vent fluids on the chemical compositions of seawater in the Manus Basin. In this study, we determined the turbidity, current velocity, $\mathrm{pH}$, $\mathrm{dFe}$, and $\mathrm{dMn}$ distributions of water columns in the PACMANUS and Desmos hydrothermal fields in an effort to understand how they vary and the relationships between $\mathrm{dFe}, \mathrm{dMn}$, physical properties, and currents in hydrothermal plumes.

\section{Geological Setting}

The eastern Manus Basin is the youngest spreading area in the Manus Basin, and it is experiencing extension within a remnant Eocene-Oligocene island-arc crust spreading at a rate of 13.5-14.5 cm/y [25] (Figure 1(a)). There are five main hydrothermal fields in the Manus Basin, namely, the PACMANUS field, Desmos caldera (23 km east of PACMANUS), Susu Knolls field ( $40 \mathrm{~km}$ east of PACMANUS), Solwara 12 $\left(3.7087^{\circ} \mathrm{S}, 151.8833^{\circ} \mathrm{E}\right)$, and Vienna Woods $\left(3.1645^{\circ} \mathrm{S}\right.$, $\left.150.2795^{\circ} \mathrm{E}\right)[24,26-31]$ (Figure 1(b)).

The PACMANUS field, which is located on the Pual Ridge, is notable for its distinctly siliceous volcanic host rocks 
(rhyodacite) and features various sulfides and Fe-Si-Mn oxyhydroxides $[26,32]$. The geochemical characteristics of PACMANUS vent fluids, such as negative $\delta \mathrm{D}_{\mathrm{H}_{2} \mathrm{O}}$ and $\delta^{34} \mathrm{~S}_{\mathrm{H}_{2} \mathrm{~S}}$ values, low $\mathrm{pH}$ values (at $25^{\circ} \mathrm{C}$ ), high $\mathrm{F}$ concentration, and high $\mathrm{CO}_{2}$ content, reflect magmatic water input, magma degassing, and seawater ingress into the upflow zone [29]. In addition, the ${ }^{87} \mathrm{Sr} /{ }^{86} \mathrm{Sr}$ and $\delta^{34} \mathrm{~S}$ signatures of anhydrite recovered at Roman Ruins and Snowcap and the multiple -S isotope compositions of hydrothermal vent fluid $\mathrm{H}_{2} \mathrm{~S}$ and coexisting chalcopyrite in this field suggest that a complex interplay exists between hydrothermal fluids, magmatic fluids, and seawater in the PACMANUS hydrothermal system [30, 33].

Satanic Mills is an active hydrothermal field with numerous isolated discharge sites at $1695-1675 \mathrm{~m}$. The active vents emit predominantly black smoker fluids from clusters of numerous branched, thin (maximum of $10 \mathrm{~cm}$ ) chimneys. The distance between the northern and southernmost chimney clusters is approximately $100 \mathrm{~m}$. The east-west dimension of the field has a maximum width of $40 \mathrm{~m} \mathrm{[34].} \mathrm{The} \mathrm{Fenway} \mathrm{hydrothermal} \mathrm{field} \mathrm{is} \mathrm{situated}$ on the southeast flank of the Pual Ridge in a depression surrounded by steep $\left(30^{\circ}\right)$ slopes to the west, northwest, and north. Fenway consists of four clusters of hydrothermal vents and a central black smoker complex (Big Papi) at a depth of approximately $1715 \mathrm{~m}$. In 2006, the Big Papi mound was the most vigorously venting black smoker site of PACMANUS. In 2011, the discharge of black smoker fluids declined. Diffuse venting is prominent in the immediate vicinity of Big Papi, which is manifested by shimmering water streaming up from the surrounding anhydrite sand and sediment [34].

The Desmos caldera, which is hosted by a more mafic basaltic andesite host rock [35], is slightly elongated in the north-northwest direction with dimensions of $1.5 \mathrm{~km}$ by $2.0 \mathrm{~km}$ and a deep circular depression of approximately $150-250 \mathrm{~m}$ [36]. The white smoker fluids rich in sulfate with a low $\mathrm{pH}$ of 0.95 to 2.10 and temperatures of $70^{\circ} \mathrm{C}$ to $120^{\circ} \mathrm{C}$ were discovered at the northwest terrace of the Desmos caldera during the 1995 Manus Flux cruise, which was named the Onsen hydrothermal site [28, 31, 36]. Similar to the North $\mathrm{Su}$ fluid, abundant $\mathrm{CO}_{2}, \mathrm{SO}_{2}$, and excess $\mathrm{F}$ in the Onsen fluid indicate magma degassing; the alteration assemblage of basaltic andesite from the Desmos caldera is thought to be formed by the interaction of basaltic andesite and hot acidic fluid (up to $340^{\circ} \mathrm{C}$ ) originating from the mixing of magmatic fluid and seawater [37].

\section{Sampling and Analytical Methods}

3.1. Sample and Physical Data Collection. During the MANUS cruise of R/V KEXUE in 2015, 18 hydrocast stations were set up in the water column above the PACMANUS (9 stations) and Desmos (9 stations) hydrothermal fields, among which the seawater and hydrothermal plume samples were collected at 8 stations (Figures 1(c) and 1(d)). We followed the methods of Zeng et al. [38]. The seawater and hydrothermal plume samples were collected at different depths with a Conductivity-Temperature-Depth (CTD) alu- minum rosette (Seabird) containing twenty-four $10 \mathrm{~L}$ Niskin bottles. To ensure the highest possible purity of the samples, the Niskin bottles were cleaned thoroughly using $1 \% \mathrm{v} / \mathrm{v}$ $\mathrm{HNO}_{3}$ solution and Milli-Q water before usage.

Upon recovery of the Niskin bottles, $30 \mathrm{~cm}$ long Teflon tubes were inserted through the outlet at the bottom of the Niskin bottles, and the first $200 \mathrm{ml}$ of the liquid was discarded. The remaining aqueous samples were collected in $5 \mathrm{~L}$ precleaned high-density polyethylene bottles. The precleaning method is described in detail by Cutter et al. [39].

During the operation of each station, data were collected throughout the seawater column with an SBE 911plus CTD system (Seabird) coupled to a Seapoint turbidity meter and a lowered acoustic Doppler current profiler (LADCP). The probes were obtained from the manufacturers and calibrated by the National Center of Ocean Standards and Metrology in July 2013. The measurement accuracies were $\pm 0.001^{\circ} \mathrm{C}$ for temperature, $\pm 0.0003 \mathrm{~S} / \mathrm{m}$ for conductivity, $\pm 0.015 \%$ of the full-scale range for pressure, $\pm 0.005 \mathrm{~m} / \mathrm{s}$ for velocity $(0.5 \%$ of the water velocity relative to LADCP), and $\pm 25^{\prime}$ for direction, with resolutions of $\pm 0.0002^{\circ} \mathrm{C}, \pm 0.0003 \mathrm{~S} / \mathrm{m}, \pm 0.0015 \%$ of the full-scale range, $0.001 \mathrm{~m} / \mathrm{s}$, and $0.01^{\circ}$, respectively. The turbidity sensitivity was $200 \mathrm{mV} / \mathrm{FTU}$ (100x gain; range of 25 FTU) [38].

3.2. Analytical Methods. The $\mathrm{pH}$ of each aqueous sample was determined by a portable $\mathrm{pH}$ meter (JENCO 6010; resolution of 0.01 with automatic temperature compensation) immediately after collection at approximately $25^{\circ} \mathrm{C}$. The $\mathrm{pH}$ meter was calibrated with buffer solutions of $\mathrm{pH} 4.00(0.050 \mathrm{~mol} / \mathrm{L}$ of potassium hydrogen phthalate) and $6.86(0.025 \mathrm{~mol} / \mathrm{L}$ of mixed phosphate). The aqueous samples were filtered through a $47 \mathrm{~mm}$ Merck Millipore $0.10 \mu \mathrm{m}$ nitrocellulose membrane into $1 \mathrm{~L}$ Nalgene polypropylene bottles (previously soaked in $1: 1 \mathrm{HNO}_{3}$ for $48 \mathrm{~h}$ and washed to neutral $\mathrm{pH}$ with deionized water and ultrapure water) within the ship laboratory immediately after collection from the Niskin bottles [38]. Filtered water samples were acidified to a $\mathrm{pH}$ of 1.8 using $2 \mathrm{M}$ ultrapure $\mathrm{HNO}_{3}$ (J. T. Baker), capped tightly, and resealed with a Parafilm sealing membrane.

For the determination of $\mathrm{Na}, \mathrm{Mg}, \mathrm{Ca}$, and $\mathrm{K}$, the filtered and acidified samples were diluted 10 times by pure water and the concentrations of dissolved $\mathrm{Na}, \mathrm{Mg}, \mathrm{Ca}$, and $\mathrm{K}$ in the aqueous samples were measured by inductively coupled plasma optical emission spectrometry (PE 2100DV) with a precision greater than $\pm 5 \%$ at the Shandong Institute of Geophysical and Geochemical Exploration [38]. For the determination of $\mathrm{Cl}$ and $\mathrm{SO}_{4}{ }^{2-}$, the samples were diluted 200 times by pure water and the $\mathrm{Cl}$ and $\mathrm{SO}_{4}{ }^{2-}$ concentrations were measured by ion chromatography (ICS-1100) with an anion exchange resin column (Dionex AS19) rinsed with a solution of $1.8 \mathrm{mmol} / \mathrm{L}$ of $\mathrm{Na}_{2} \mathrm{CO}_{3}$ and $1.7 \mathrm{mmol} / \mathrm{L}$ of $\mathrm{NaHCO}_{3}$ at a rinsing rate of $1 \mathrm{~mL} / \mathrm{min}$ and precision of $\pm 3 \%$ [38]. The accuracy was controlled by the recovery; for $\mathrm{Na}, \mathrm{Mg}, \mathrm{Ca}, \mathrm{K}$, $\mathrm{Cl}$, and $\mathrm{SO}_{4}{ }^{2-}$, the recovery rates were $99.5 \%, 99.6 \%, 99.8 \%$, $99.7 \%, 99.7 \%$, and $100.1 \%$, respectively.

The dFe and dMn contents of the seawater and plume samples were determined by inductively coupled plasma 
sector field mass spectrometry (Element, Thermo Scientific) at ALS Scandinavia AB, Luleå, Sweden, in accordance with the method described by Rodushkin and Ruth [40]. Reference materials NASS-6 (North Atlantic Seawater) and CASS-5 (Nearshore Seawater) from the National Research Council of Canada were used to evaluate the accuracy of the $\mathrm{dFe}$ and $\mathrm{dMn}$ analyses, and accuracies and precision $(n=5)$ greater than $5 \%$ were achieved for both [38].

\section{Results}

4.1. Element Concentrations in Seawater Columns. The concentrations of major components $(\mathrm{Ca}, \mathrm{Mg}, \mathrm{K}, \mathrm{Na}, \mathrm{Cl}$, and $\mathrm{SO}_{4}{ }^{2-}$ ) in the Satanic Mills and Fenway vent fluids [29] were different from those of the bottom seawater. Their profiles in the water column samples collected above the PACMANUS and Desmos fields exhibited slight variation (Tables 1 and 2). The highest dissolved $\mathrm{Ca}(10.2 \mathrm{mmol} / \mathrm{kg})$ concentrations were observed in the background seawater samples (depth shallower than $800 \mathrm{~m}$ ) from the Desmos field, and dissolved $\mathrm{Na}(432.0 \mathrm{mmol} / \mathrm{kg})$ concentrations were observed in the seawater column samples (depth deeper than $1200 \mathrm{~m}$ ) in the Fenway vent site from the PACMANUS field (Tables 1 and 2). However, the concentrations of dissolved $\mathrm{K}(9.72-11.5 \mathrm{mmol} / \mathrm{kg}), \mathrm{SO}_{4}{ }^{2-}(28.3-$ $30.9 \mathrm{mmol} / \mathrm{kg}), \quad \mathrm{dFe}(0.010-0.133 \mathrm{mmol} / \mathrm{kg})$, and $\mathrm{dMn}$ $(0.001-0.539 \mathrm{mmol} / \mathrm{kg})$ and the $\mathrm{pH}$ of the seawater profiles in the PACMANUS and Desmos fields were significantly more variable and greater than those of ambient seawater, except for $\mathrm{pH}$, which was lower (7.49 to 8.14) (Tables 1 and 2; Figures 2 and 3). At stations P-W07, P-W02, $\mathrm{P}-\mathrm{W} 01$, and P-W04 in the PACMANUS field, from a depth of $1200 \mathrm{~m}$ to the bottom, the turbidity and dFe increased relative to that in the seawater shallower than $1200 \mathrm{~m}$, and $\mathrm{pH}$ showed a decreasing trend with the lowest value of 7.49 observed at $1665 \mathrm{~m}$ at P-W04. However, the concentration of dMn began to increase from different depths at these four stations (Figure 2).

\subsection{Physical and Chemical Characteristics of Hydrothermal} Plumes. Station P-W02 was located at the Satanic Mills vent site, and station P-W04 was located at the Fenway vent site (Figure 1(c)). As the hydrothermal plumes above the Satanic Mills (P-W02) and Fenway (P-W04) vent sites dispersed laterally, the anomalous turbidity layer also dispersed (Figure 2), which was identical to that in the middle plume observed by Gamo et al. [23] during the second cruise of the AQUARIUS Expedition (KH-90-3) in 1990. The turbidity anomaly was $400-500 \mathrm{~m}$ thick with values 2-5 times greater than those of the background seawater, which was similar to that observed in the Manus Basin in 1990 [22]. At P-W02, the maximum turbidity (0.475 $\mathrm{NTU}), \mathrm{dMn}(0.533 \mu \mathrm{mol} / \mathrm{kg})$, and $\mathrm{dFe}(0.058 \mu \mathrm{mol} / \mathrm{kg})$ anomalies were found at $1550 \mathrm{~m}$, and at $\mathrm{P}-\mathrm{W} 04$, the maximum turbidity $(0.484 \mathrm{NTU}), \mathrm{dMn}(0.539 \mu \mathrm{mol} / \mathrm{kg})$, and $\mathrm{dFe}$ $(0.133 \mu \mathrm{mol} / \mathrm{kg}$ ) anomalies were found at $1526 \mathrm{~m}$ (Table 1 ; Figure 2). According to the anomalous layer with the maximum dMn concentration, the Satanic Mills plume rose approximately $140 \mathrm{~m}$ above the seafloor, and the Fenway plume rose approximately $220 \mathrm{~m}$ above the seafloor (Figure 2). Moreover, the Satanic Mills plume and Fenway plume intersected each other at a depth between $1625 \mathrm{~m}$ and $1550 \mathrm{~m}$ (Figure 4).

At stations D-W09, D-W02, D-W01, and D-W04 in the Desmos field, from a depth of $1400 \mathrm{~m}$ to the bottom, the turbidity and dFe concentration increased relative to those of the seawater shallower than $1400 \mathrm{~m}$, and the $\mathrm{pH}$ showed a decreasing trend with the lowest value of 7.51 observed at depth of $1824 \mathrm{~m}$ at D-W01 and $1840 \mathrm{~m}$ at D-W04; however, the $\mathrm{dMn}$ concentration began to increase from a depth of $1500 \mathrm{~m}$ (Figure 3). Stations D-W01 and D-W04 were located at the inner southeast flank wall of the Desmos caldera (Figure 1(d)) where plumes were identified by anomalies of turbidity, dMn, and dFe (Figure 3). At station D-W01, the anomalous layer with the maximum $\mathrm{dMn}$ concentration $(0.101 \mu \mathrm{mol} / \mathrm{kg})$ was found at a depth of $1768 \mathrm{~m}$, which was deeper than the deep plume (approximately $1700 \mathrm{~m}$ ) observed by Gamo et al. [23] in 1990. The maximum dFe $(0.076 \mu \mathrm{mol} / \mathrm{kg})$ anomaly was found at a depth of $1800 \mathrm{~m}$, thereby indicating that the plume was $110-140 \mathrm{~m}$ above the seafloor. At station D-W04, the maximum $\mathrm{dMn}$ $(0.158 \mu \mathrm{mol} / \mathrm{kg})$ and $\mathrm{dFe}(0.084 \mu \mathrm{mol} / \mathrm{kg})$ anomalies were found at a depth of $1840 \mathrm{~m}$ (Table 2; Figure 3), so the plume rose approximately $50 \mathrm{~m}$ above the seafloor. Moreover, the significant anomalous centers of turbidity at D-W01 and D-W04 appeared alternately at different depths (Figure 5).

However, the turbidity (up to 0.484 FTU and 0.292 FTU), $\mathrm{dFe}$ (up to $0.133 \mu \mathrm{mol} / \mathrm{kg}$ and $0.084 \mu \mathrm{mol} / \mathrm{kg}$ ), and $\mathrm{dMn}$ (up to $0.539 \mu \mathrm{mol} / \mathrm{kg}$ and $0.158 \mu \mathrm{mol} / \mathrm{kg}$ ) concentrations of the P-W04, P-W02, D-W01, and D-W04 hydrothermal plumes near the Satanic Mills, Fenway, and Desmos vent sites were generally higher than those of the P-W07 and D-W09 plumes far from these vent sites (Figures 1 and 2), and the dissolved $\mathrm{Mg}(49.5 \mathrm{mmol} / \mathrm{kg}$ and $49.3 \mathrm{mmol} / \mathrm{kg})$ and $\mathrm{Ca}(9.12 \mathrm{mmol} / \mathrm{kg}$ and $9.13 \mathrm{mmol} / \mathrm{kg}$ ) concentrations of the P-W04, P-W02, DW01, and D-W04 plumes near the vent sites were generally lower than those of the plumes far from these vent sites in the PACMANUS and Desmos fields (Tables 1 and 2). Furthermore, the dissolved $\mathrm{Mg}, \mathrm{Cl}, \mathrm{dFe}$, and $\mathrm{dMn}$ concentrations of the hydrothermal plumes in the PACMANUS field near the Satanic Mills and Fenway vent sites were generally higher than those of the plumes near the Desmos vent site, and the $\mathrm{SO}_{4}{ }^{2-}$ concentrations of the plumes near the Satanic Mills and Fenway vent sites were generally lower than those of the plumes near the Desmos vent site (Tables 1 and 2; Figures 2 and 3).

\section{Discussion}

5.1. Turbidity, $d M n$, and $d F e$ in Hydrothermal Plumes. Hydrothermal plumes can be distinguished by anomalies relative to the background seawater values, including elevated $\mathrm{dFe}$ and $\mathrm{dMn}$ concentrations and turbidity. In the PACMANUS hydrothermal field, the maximum temperatures of the vent fluids of the Satanic Mills and Fenway vent sites were $345^{\circ} \mathrm{C}$ and $313^{\circ} \mathrm{C}$ in 2011 , respectively [34]. Above these vent sites, plumes were detected with high dMn concentrations that were 150-200 times that of the background 


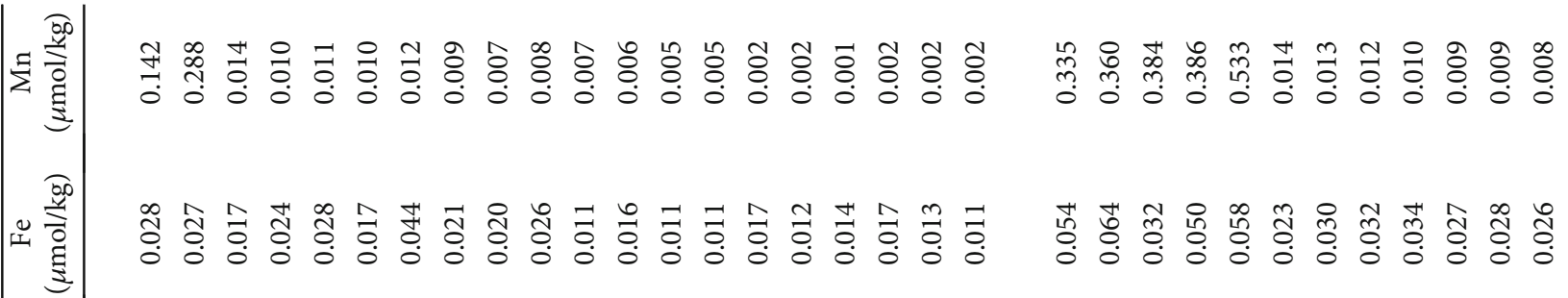


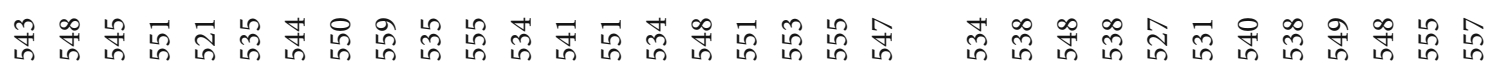

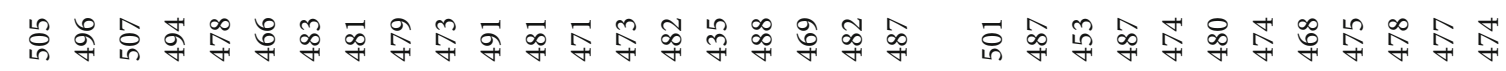

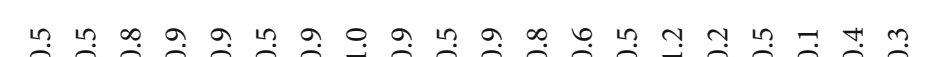

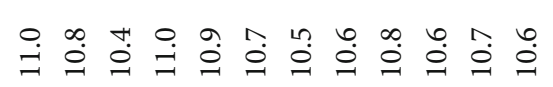

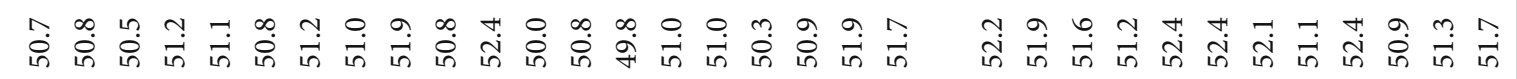

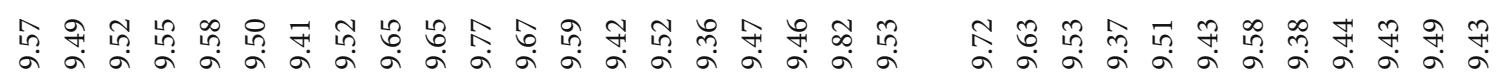

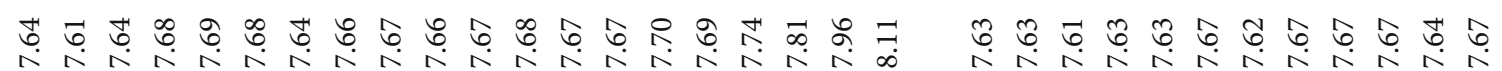

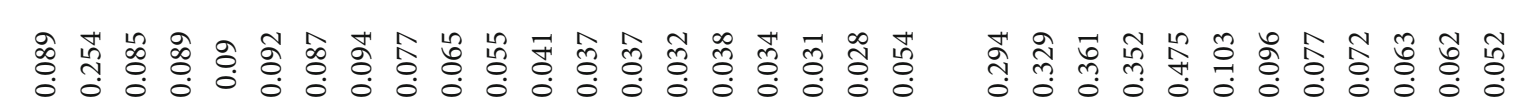

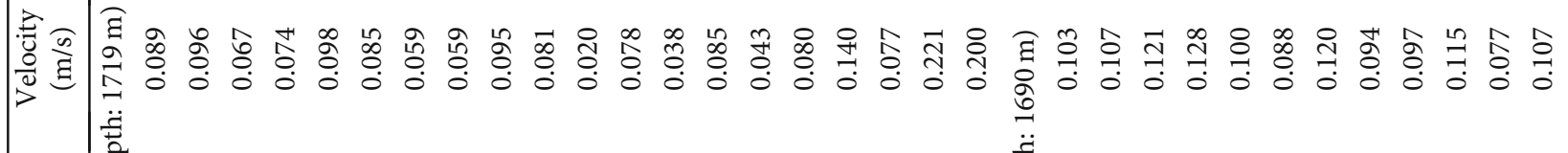

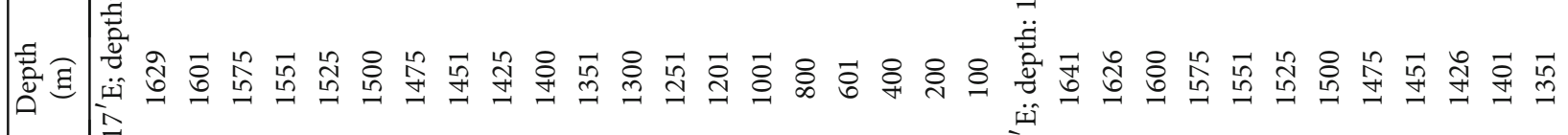

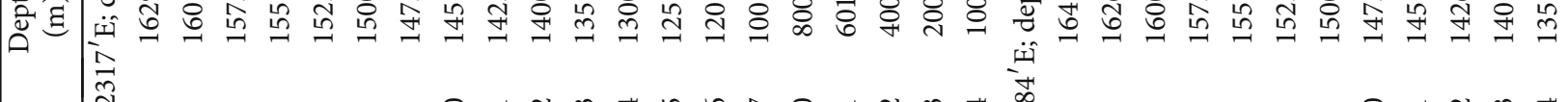

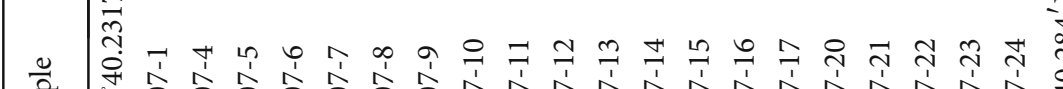

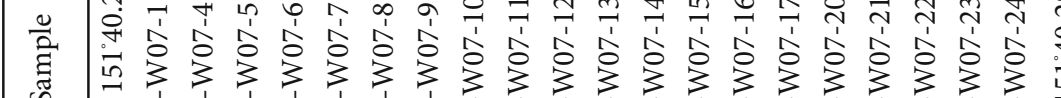

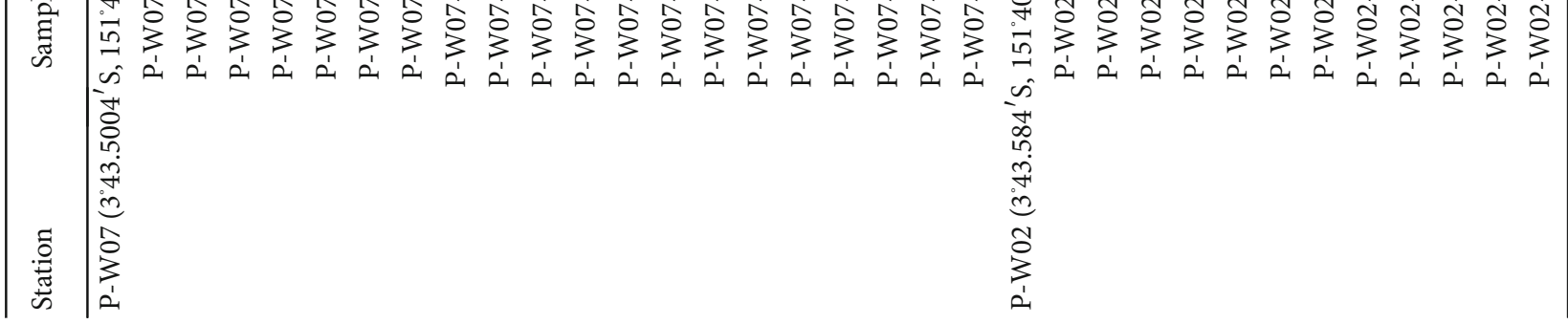




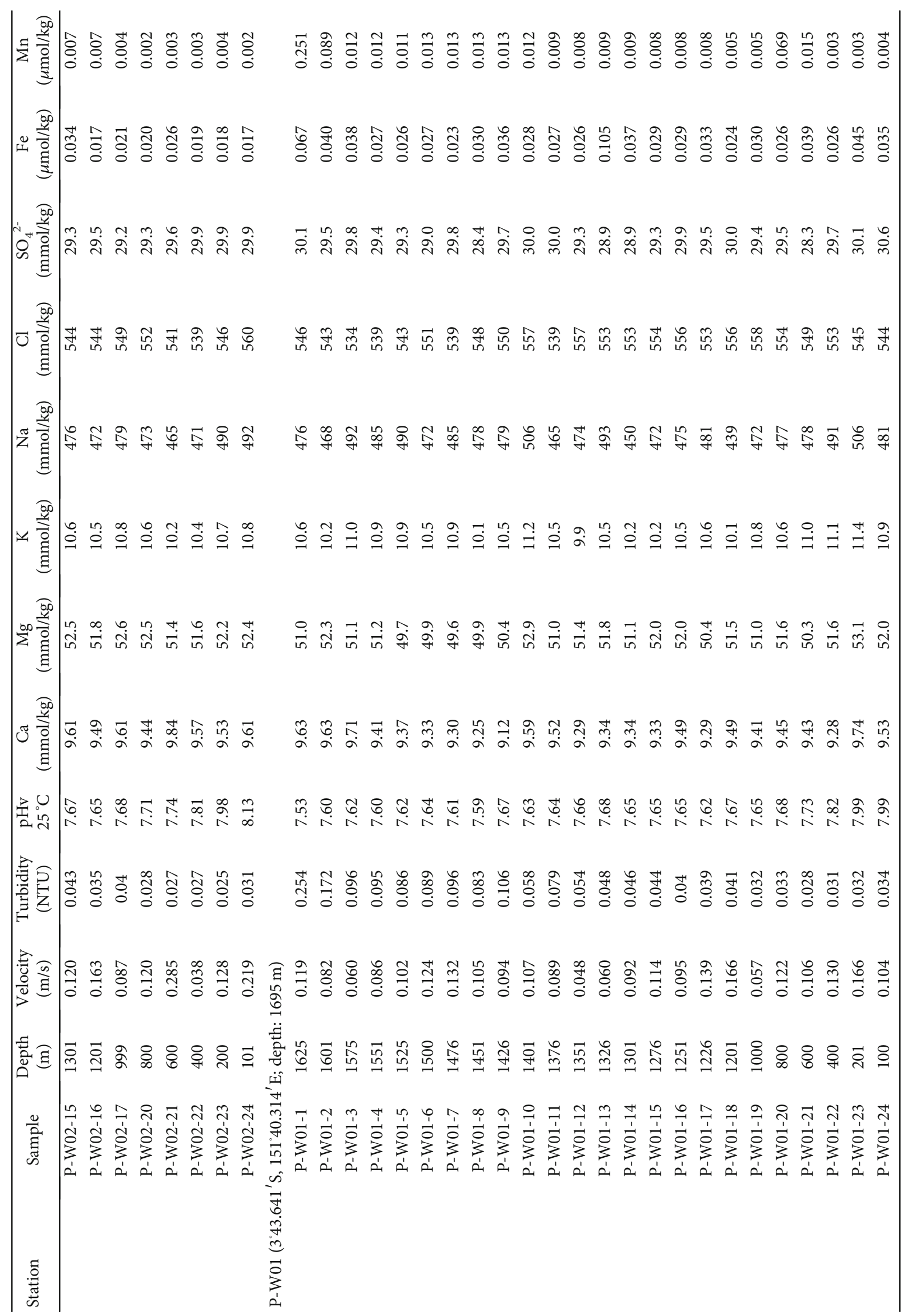




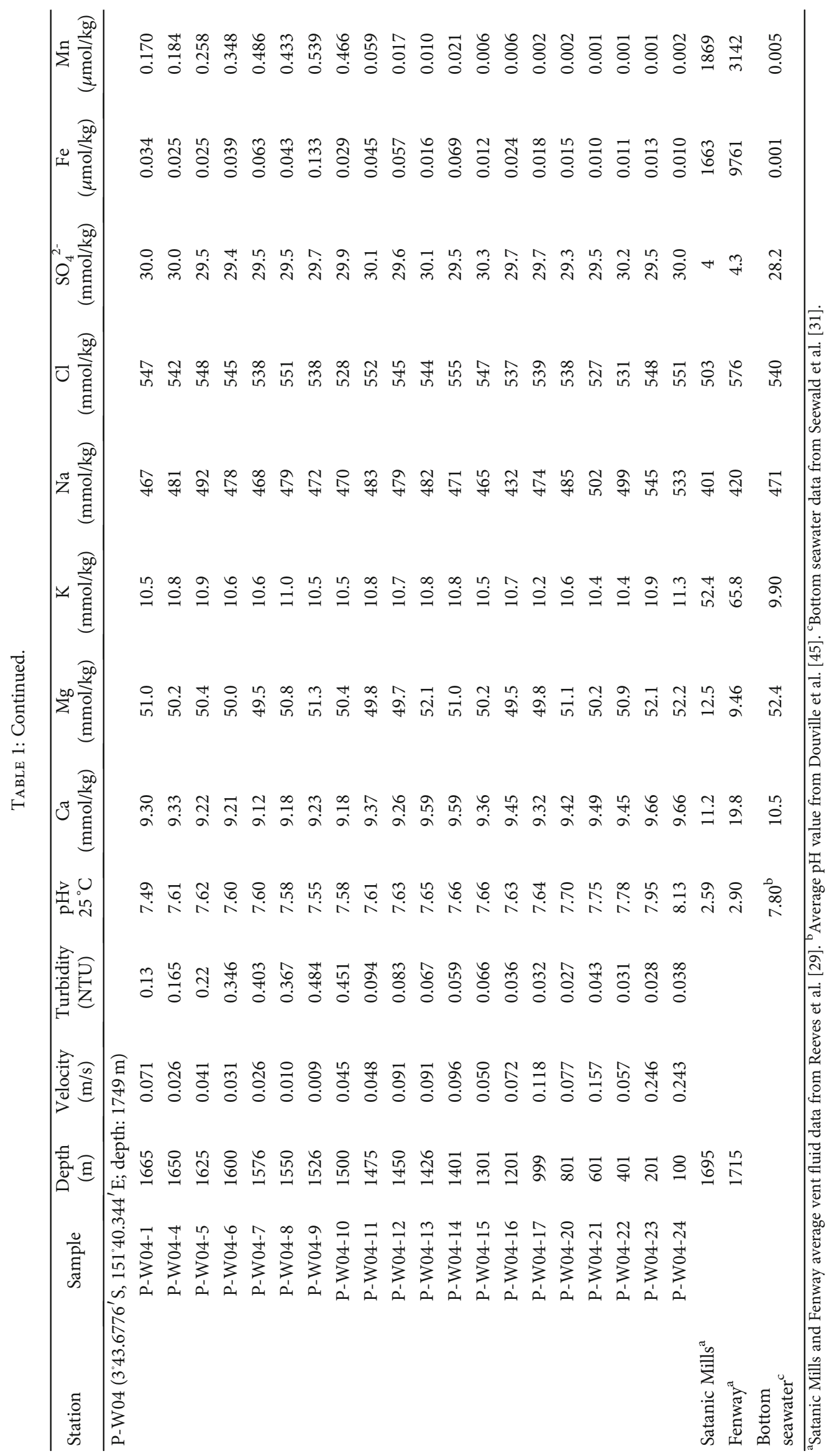




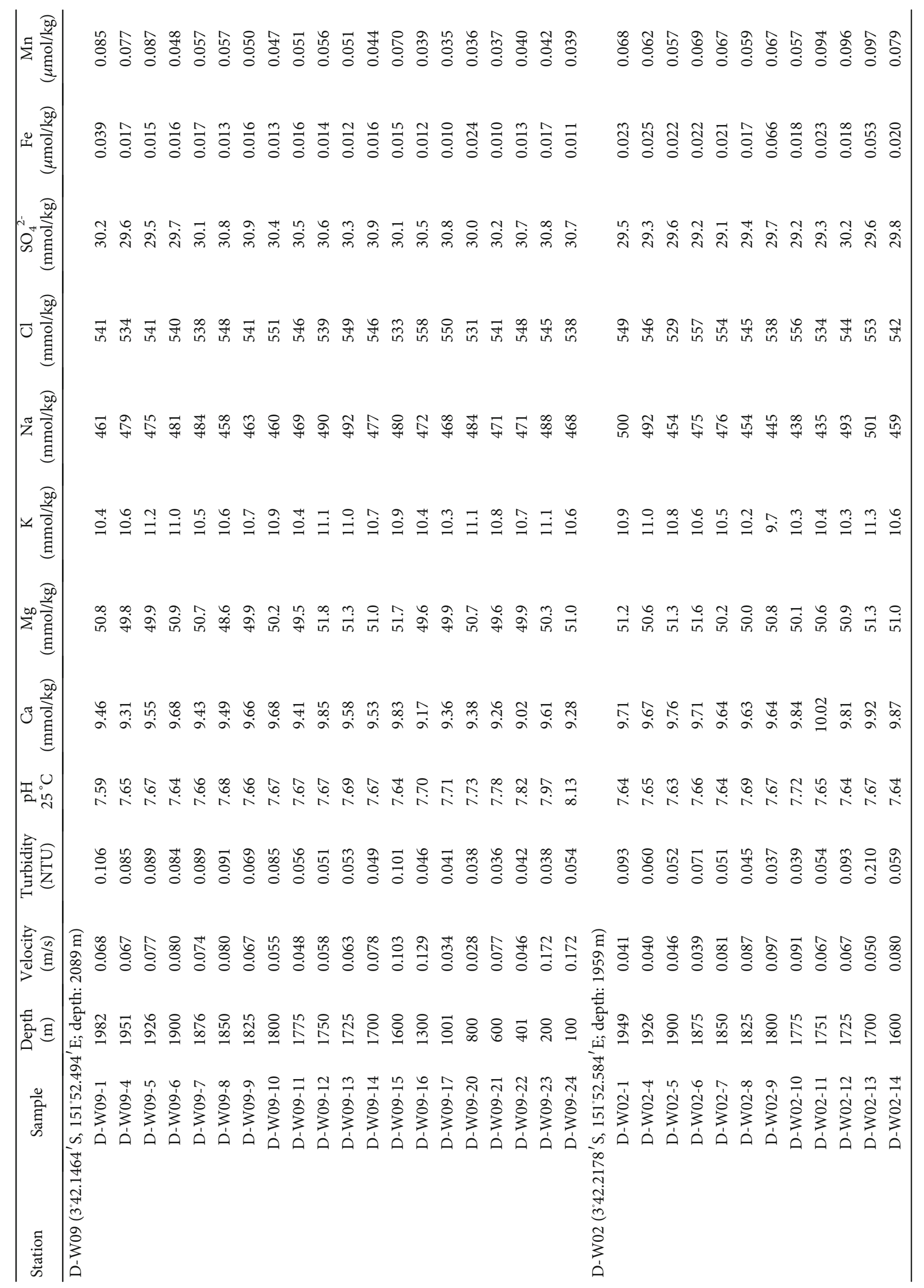




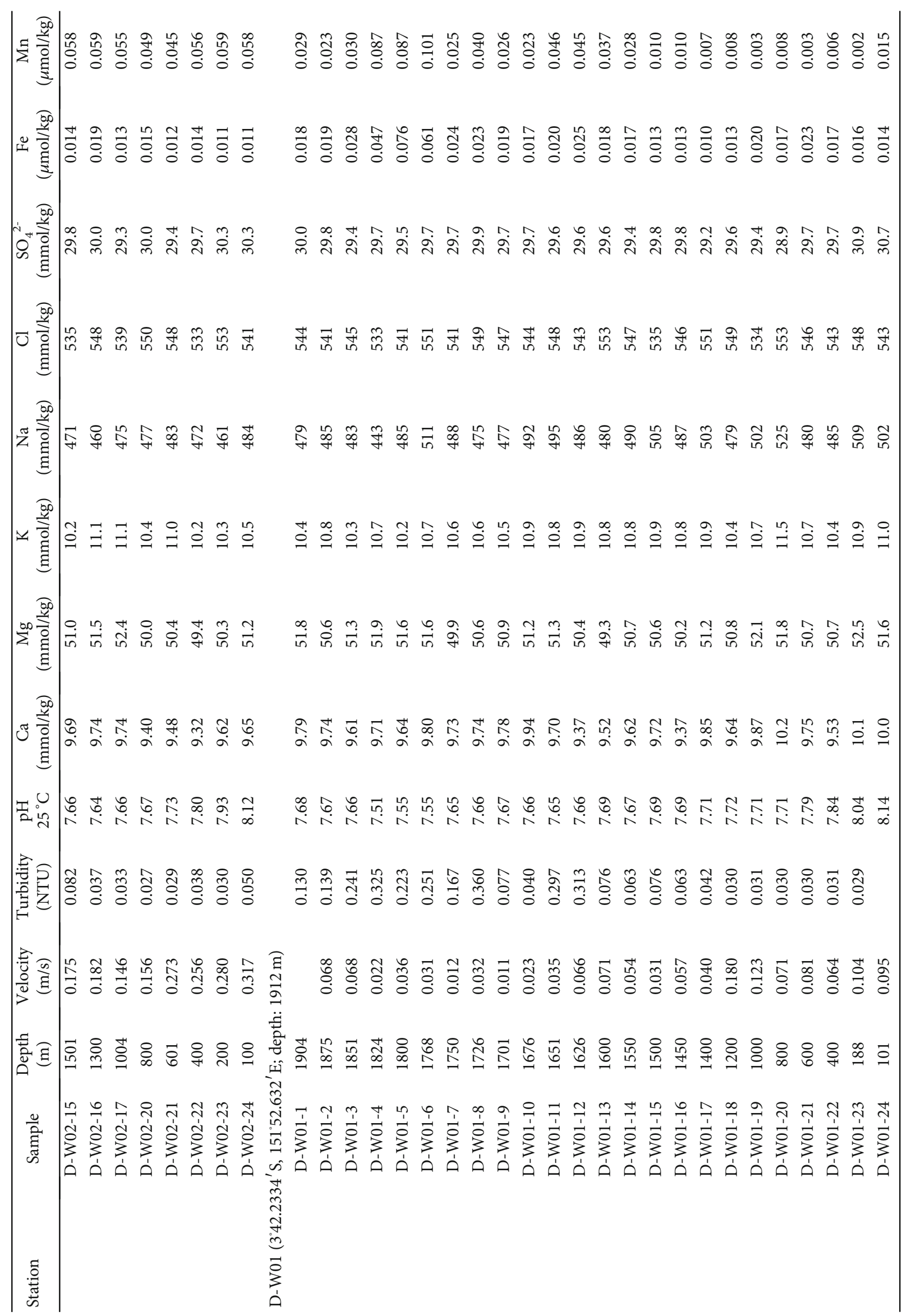




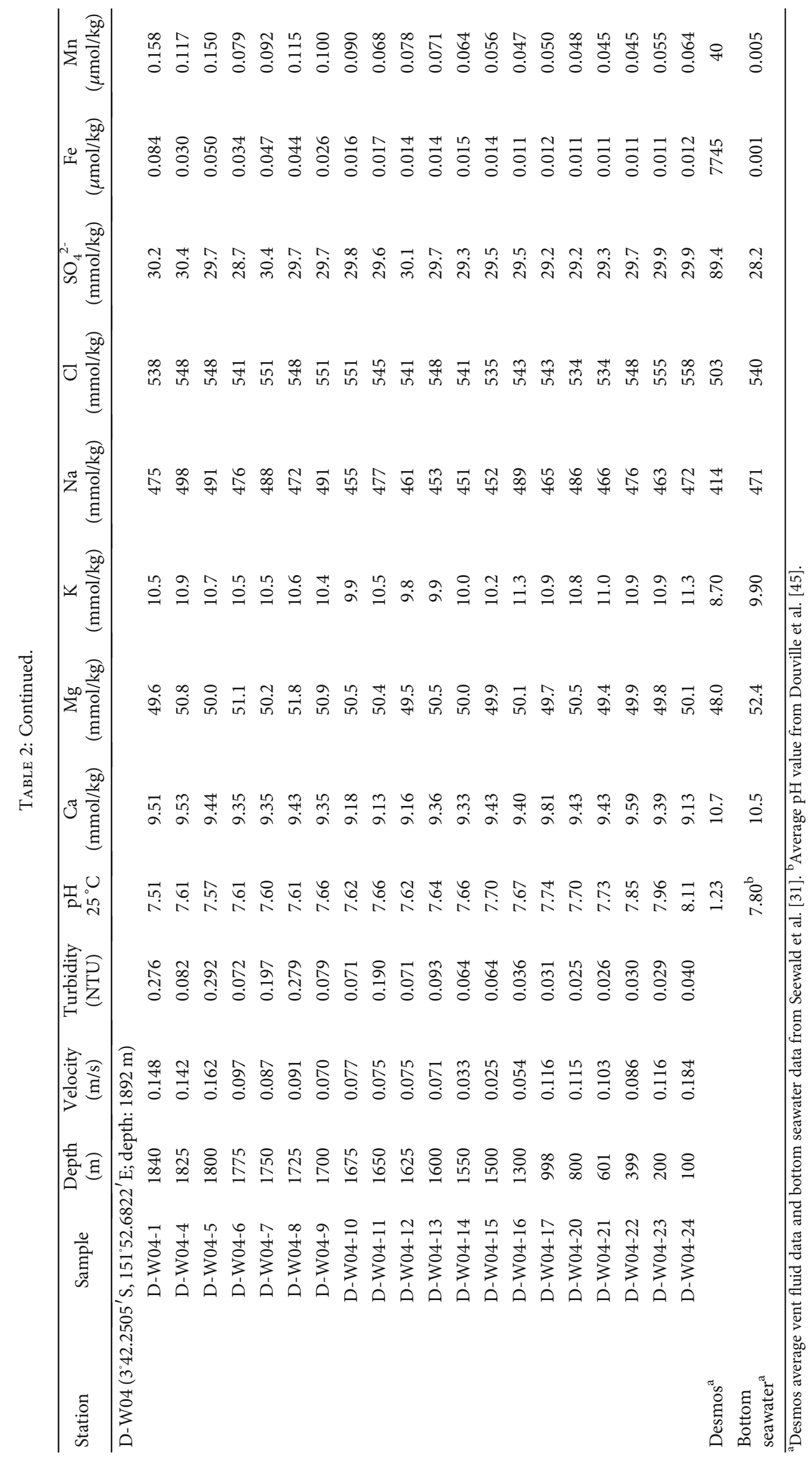




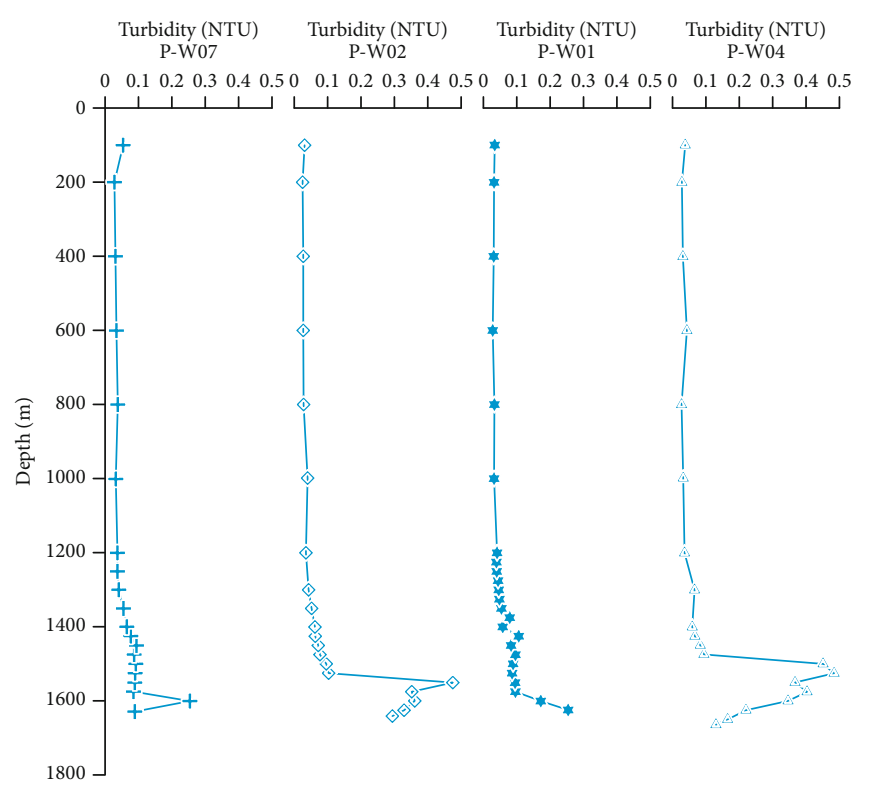

(a)

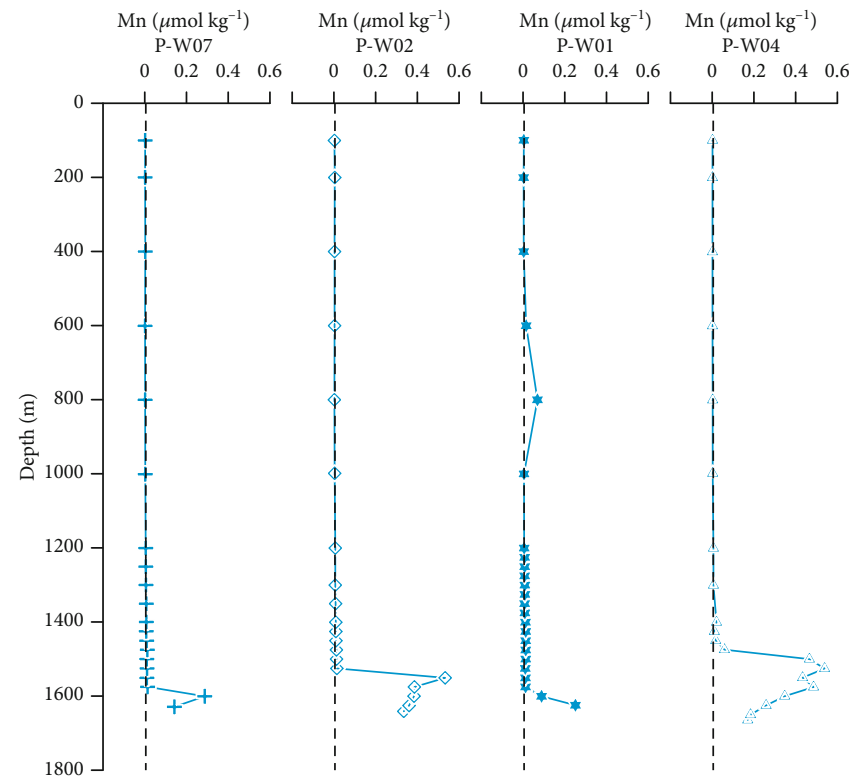

(c)

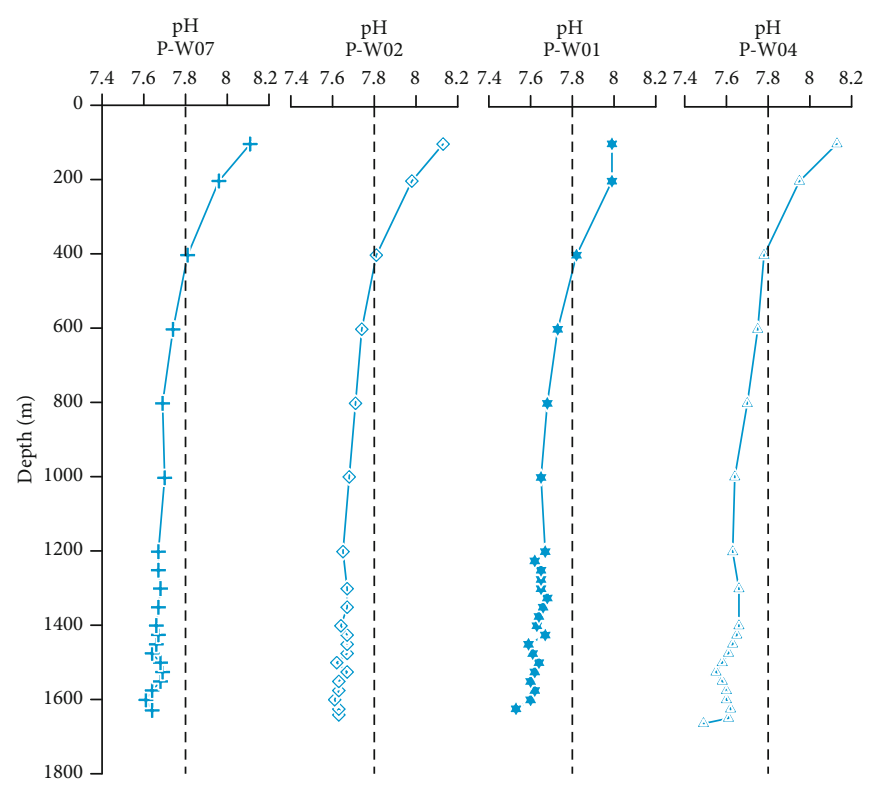

(b)

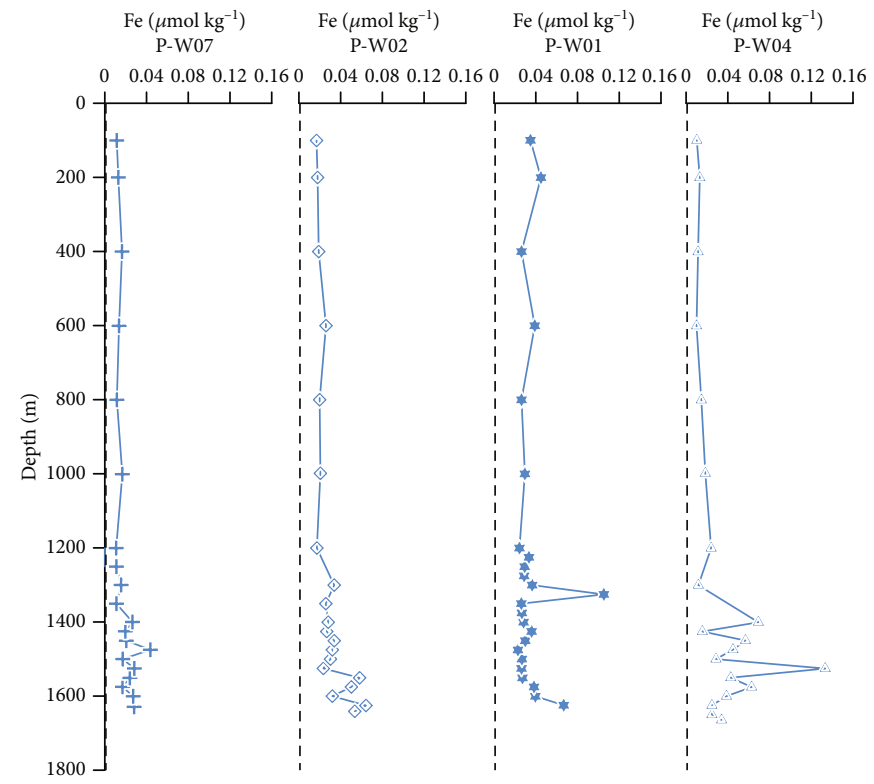

(d)

Figure 2: (a) Turbidity, (b) pH, (c) Mn, and (d) Fe anomalies in the water columns at the PACMANUS hydrothermal field (stations P-W07, P-W02, P-W01, and P-W04). The seawater composition (vertical dashed line) was obtained from Seewald et al. [31] and Douville et al. [45].

seawater (Figure 2). The maximum dMn concentration for the PACMANUS plume $(539 \mathrm{nmol} / \mathrm{kg})$ was higher than those seen elsewhere on fast $(16-194 \mathrm{nmol} / \mathrm{kg}$, East Pacific Rise) and ultraslow (0.47-10.41 nmol/kg, Southwest Indian Ridge) spreading ridges [41, 42]. The turbidity anomaly was $400-500 \mathrm{~m}$ thick with values $2-5$ times greater than that of the background seawater, which was similar to that observed in the Manus Basin in 1990 [22]. However, based on our samples, two anomalous centers were observed corresponding to the positions of the Satanic Mills and Fenway vent sites, and a continuous turbidity profile showed multipeak anomalies at different depths (Figure 2). In the Desmos field, a $600 \mathrm{~m}$ thick turbidity anomaly with values 2-4 times greater than that of the background seawater was discovered above the bottom (Figure 3), which was at the same depth $(1700 \mathrm{~m})$ as the deep plume found by Japanese scientists in 1990 [23], thereby implying that the plume in the Desmos field has existed for more than $25 \mathrm{y}$. In the PACMANUS and Desmos fields, higher turbidity, lower $\mathrm{pH}$, and higher $\mathrm{dFe}$ and $\mathrm{dMn}$ concentrations in the anomalous layer in the seawater columns were consistent with the levels of these elements in their source vent fluids in the area ([29, 31, 43]; Tables 1 and 2; Figures 2-5). 

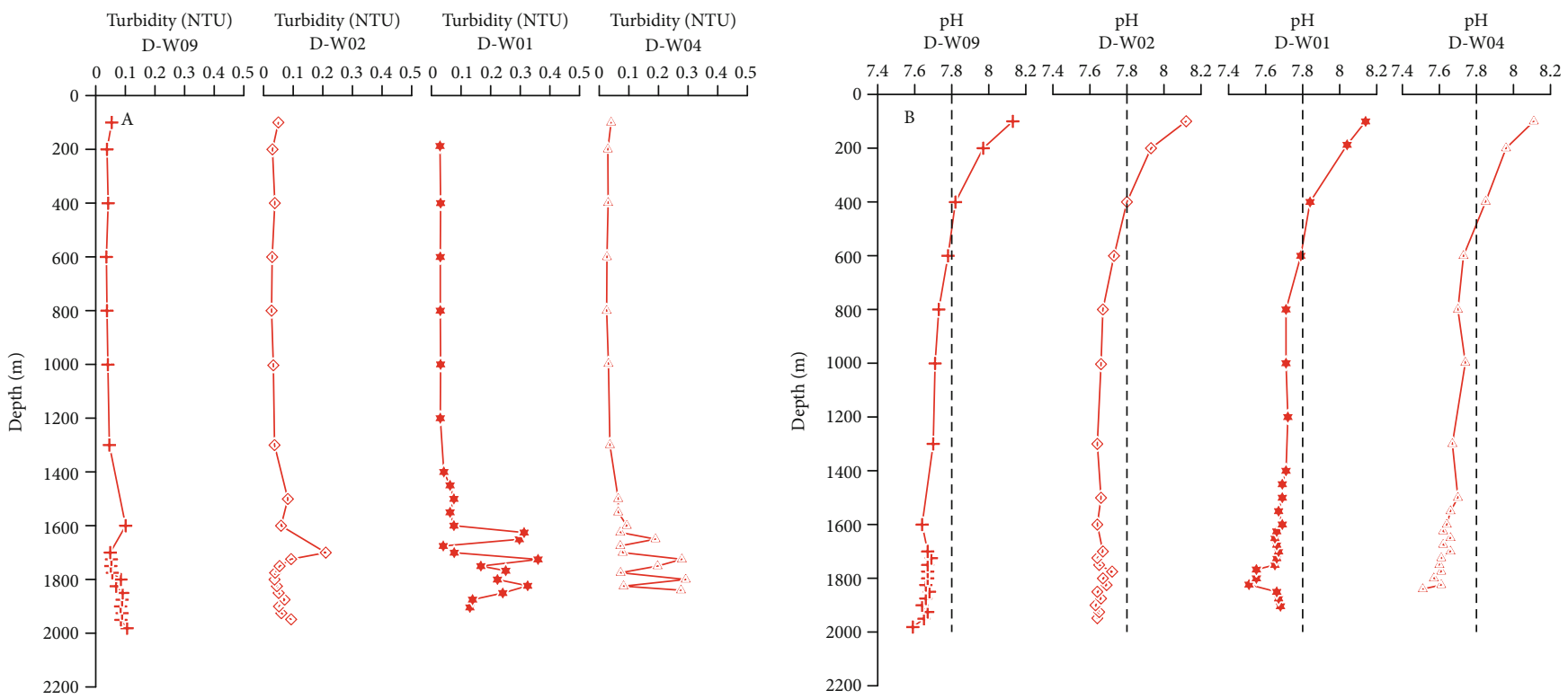

(a)

(b)
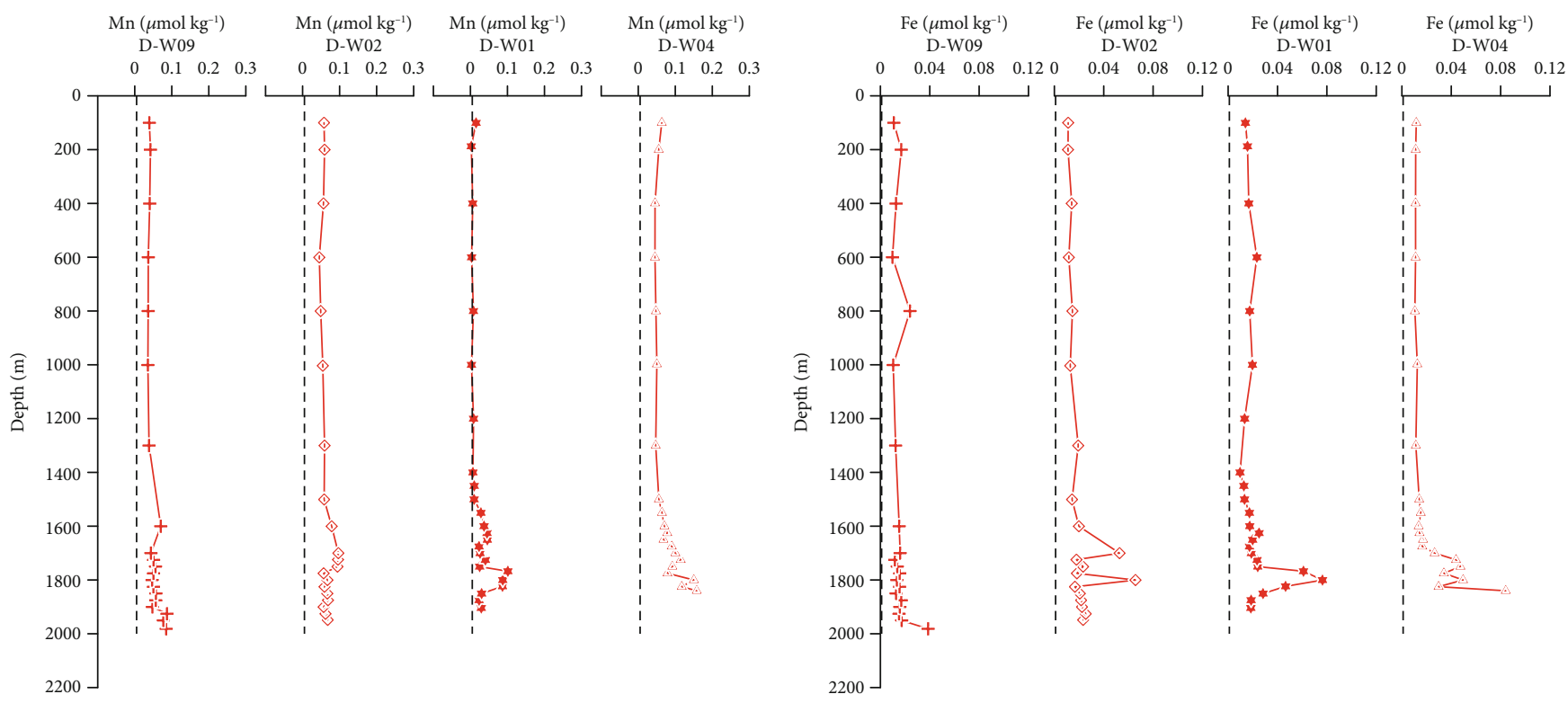

(c)

(d)

Figure 3: (a) Turbidity, (b) pH, (c) Mn, and (d) Fe anomalies in the water columns at the Desmos hydrothermal field (stations D-W09, DW02, D-W01, and D-W04). The seawater composition (vertical dashed line) was obtained from Seewald et al. [31] and Douville et al. [45].

However, at the Satanic Mills and Fenway vent sites,

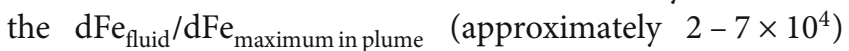
was one order of magnitude higher than the $\mathrm{dMn}_{\text {fluid }}$ / $\mathrm{dMn}_{\text {maximum in plume }}\left(3-6 \times 10^{3}\right)$, which was attributed to the rapid precipitation of $\mathrm{dFe}$ from the buoyant hydrothermal plume $[1,14]$; thus, more dFe was removed than $\mathrm{dMn}$ at the initial stage. However, the relative reductions of $\mathrm{dFe}$ and $\mathrm{dMn}$ were different from those of the initial stage when the plume dispersed laterally. In the Satanic Mills field, at the maximum Mn anomaly layer (depth of $1550 \mathrm{~m}$ ), the plume dispersed in the northwest direction according to the turbidity contour map, the current direction (Figures 4(d) and 4(f)), and the $\mathrm{dMn}$ and $\mathrm{dFe}$ concentrations at P-W02 $(0.533 \mu \mathrm{mol} / \mathrm{kg}$ of $\mathrm{dMn}$ and $0.058 \mu \mathrm{mol} / \mathrm{kg}$ of $\mathrm{dFe})$ and P-W07 $(0.010 \mu \mathrm{mol} / \mathrm{kg}$ of $\mathrm{dMn}$ and $0.024 \mu \mathrm{mol} / \mathrm{kg}$ of $\mathrm{dFe}$, northwest of P-W02). At this layer, from near the center of the plume ( $\mathrm{P}$ W02) to a distal location (P-W07), the relative reduction of $\mathrm{dFe}$ was $59 \%$, which was lower than that of $\mathrm{dMn}$ (98\%), thereby suggesting that $\mathrm{dFe}$ was removed more slowly than $\mathrm{dMn}$ when the plume dispersed laterally, which might have been related to the formation of small inorganic nanoparticles [16-18], complexation by organic ligands [19-21], and reversibility of exchange onto slowly sinking particles [12]. 


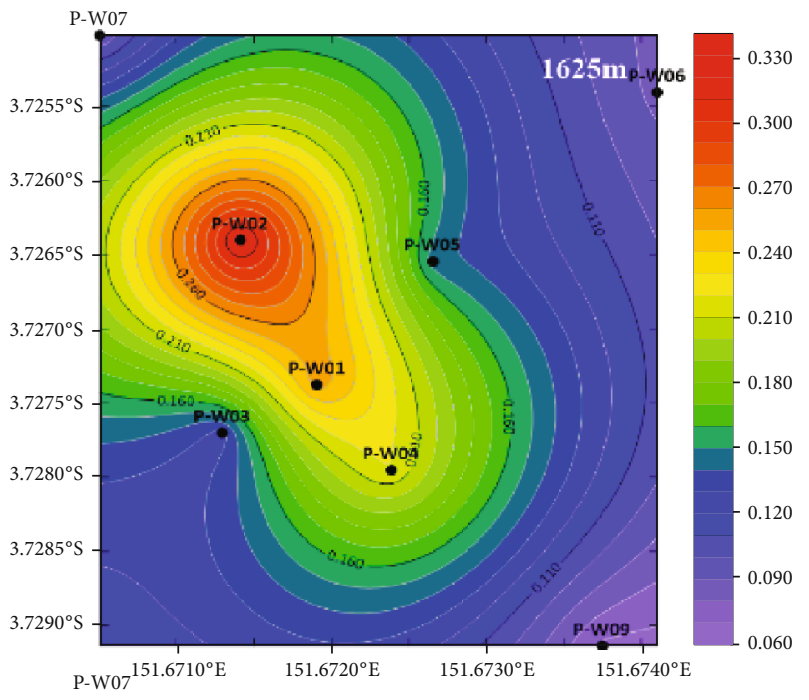

(a)

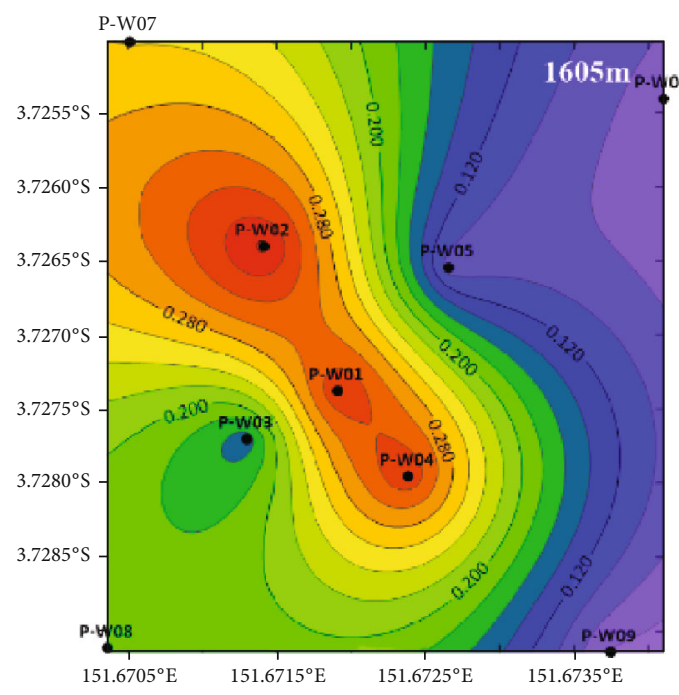

(c)

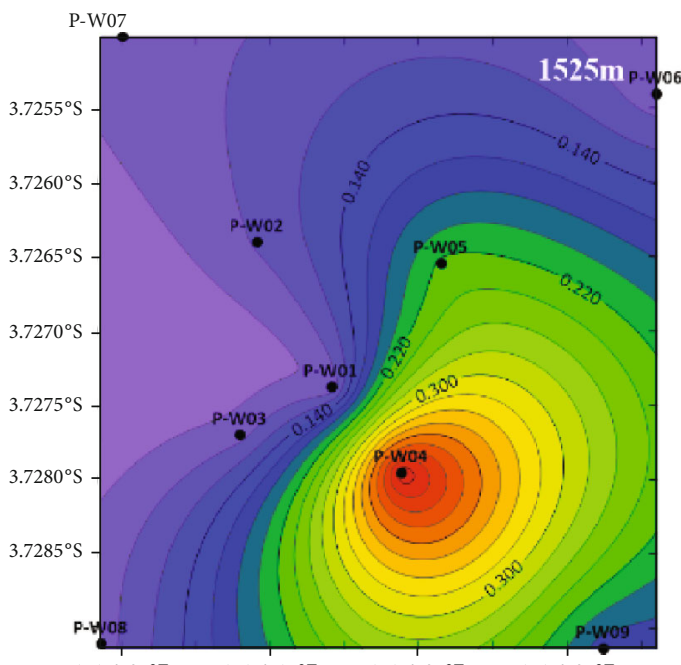

(e)

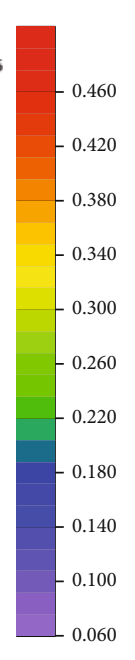

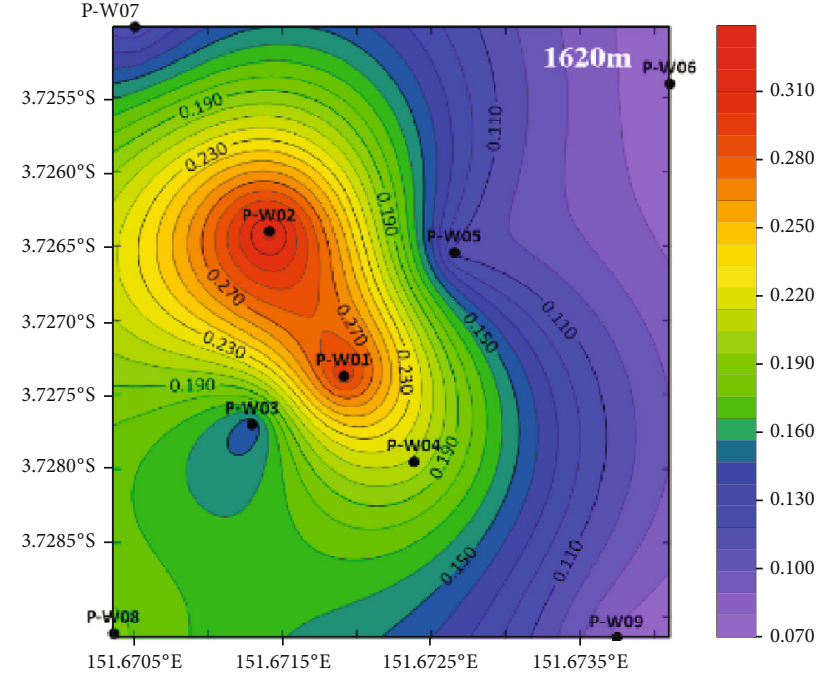

(b)

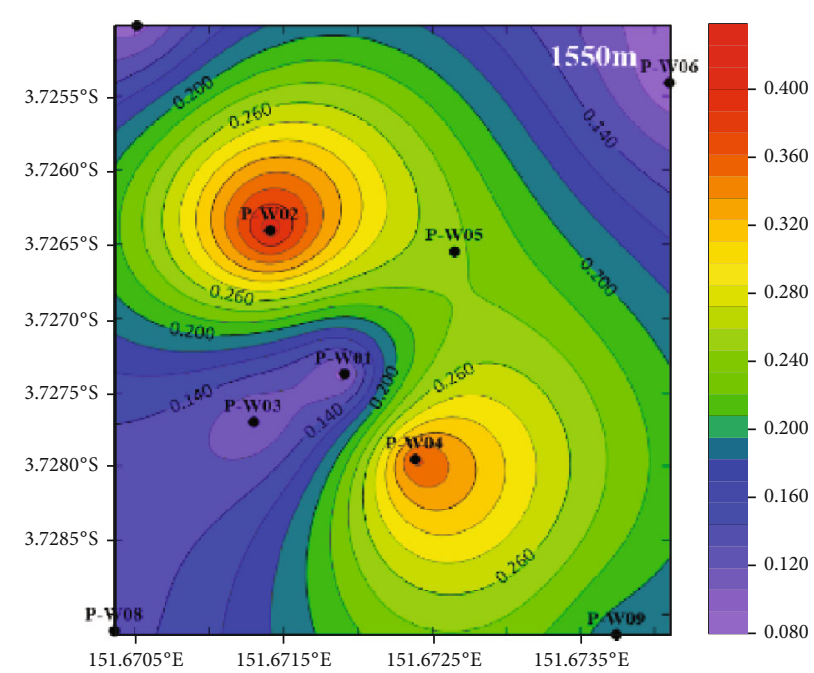

(d)

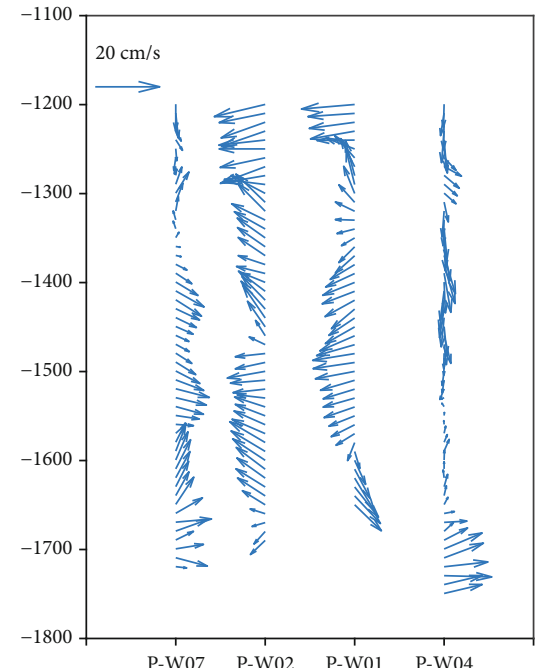

(f)

FIGURE 4: Turbidity contour and current velocity map of the PACMANUS hydrothermal field. 


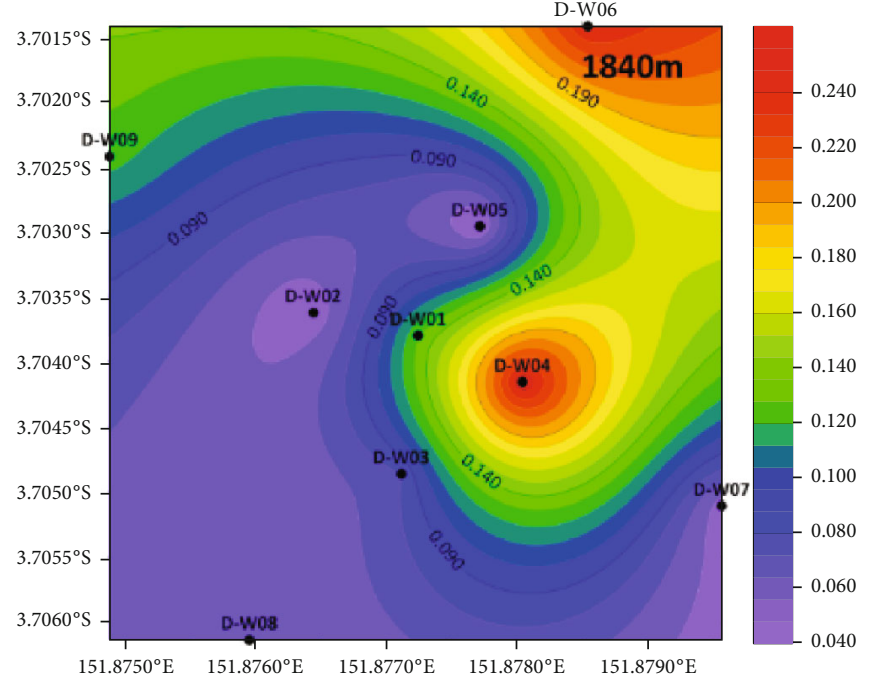

(a)

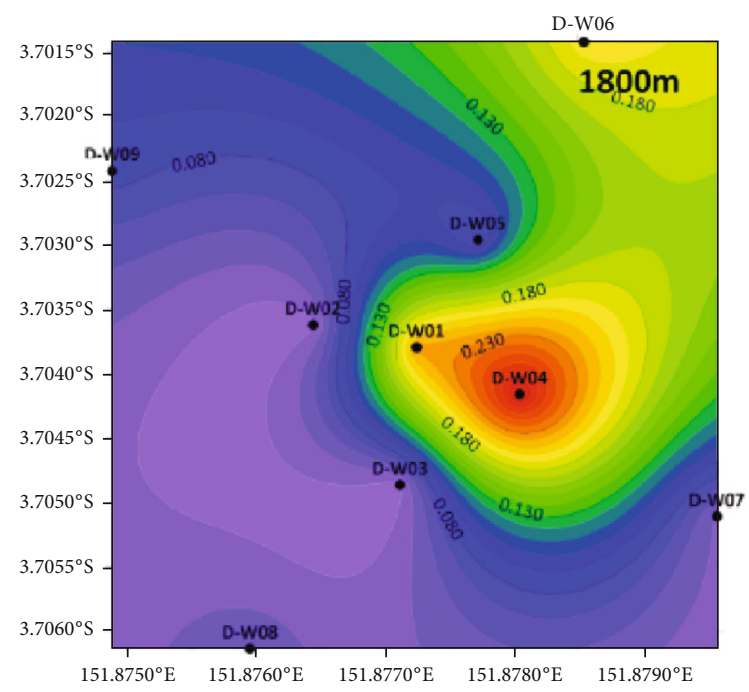

(c)

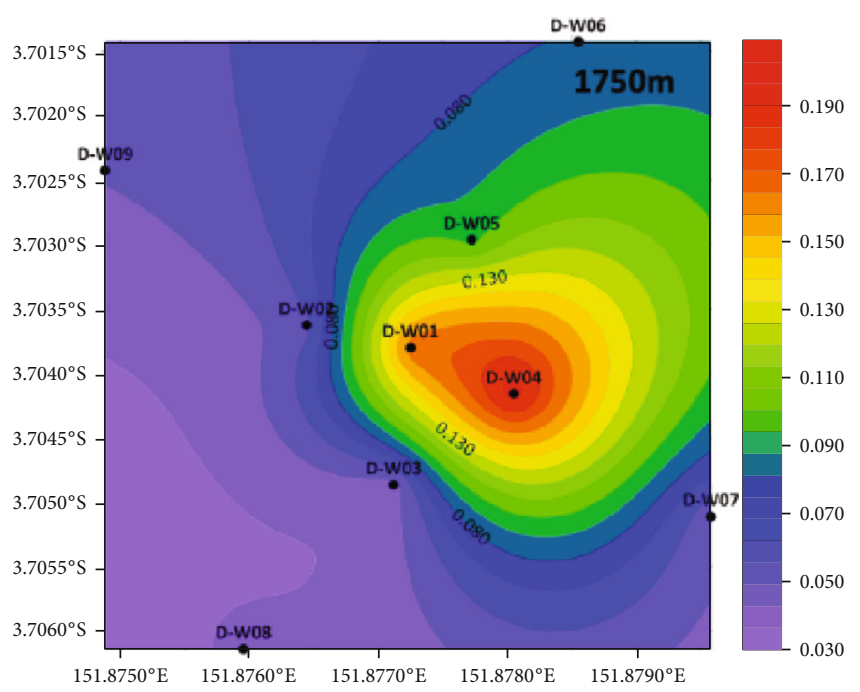

(e)

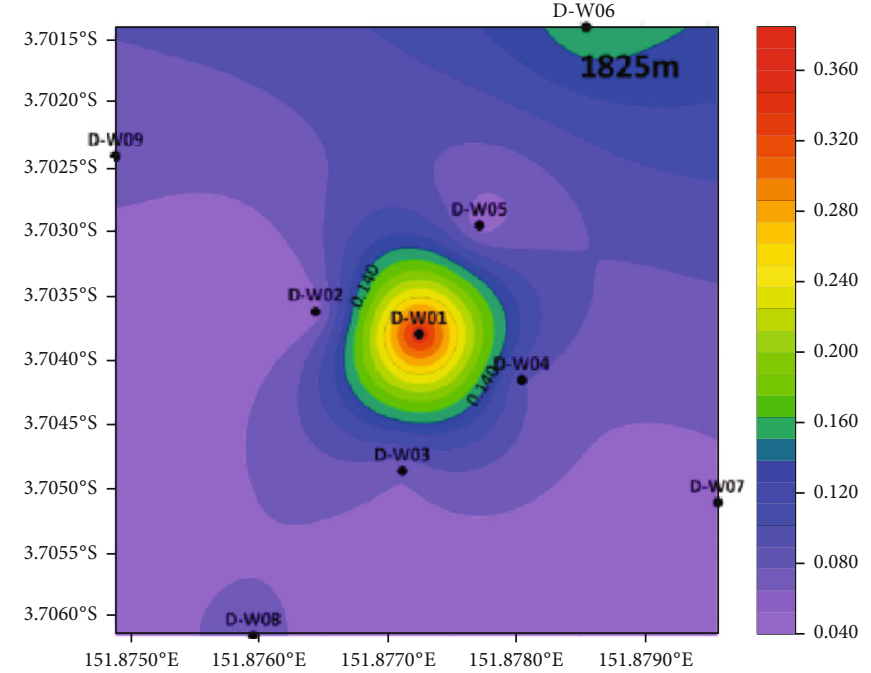

(b)

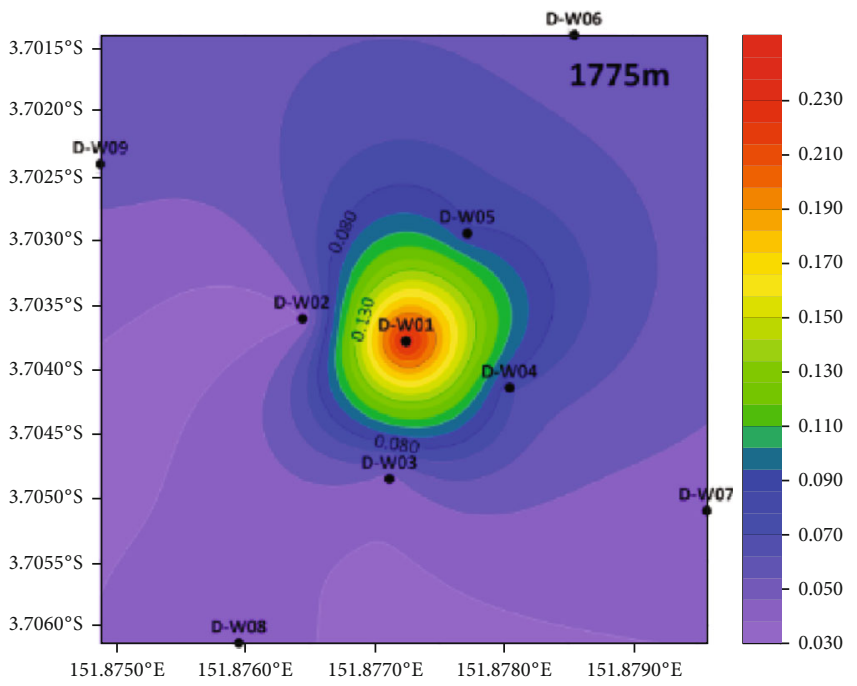

(d)

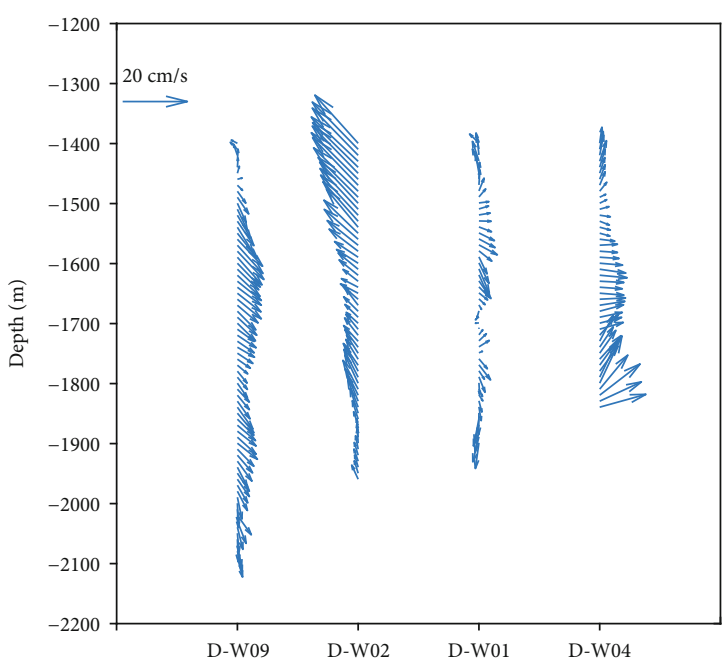

(f)

Figure 5: Turbidity contour and current velocity map of the Desmos hydrothermal field. 
5.2. Distinguishing Fluid Sources by Their Chemical Components in Hydrothermal Plumes. The dissolved Mg, $\mathrm{Cl}, \mathrm{dFe}$, and $\mathrm{dMn}$ concentrations in the hydrothermal plumes above the PACMANUS field, near the Satanic Mills (station P-W02) and Fenway (station P-W04) vent sites, were generally higher than those in the plumes near the Desmos vent site (stations D-W01 and D-W04), whereas the $\mathrm{SO}_{4}{ }^{2-}$ concentrations near the PACMANUS field vent sites were generally lower than those in the plumes immediately above the Desmos field vent site (Tables 1 and 2; Figures 2 and 3), thereby suggesting that the extent of dilution of the hydrothermal fluid with seawater was weaker in the PACMANUS field than in the Desmos field. These differences were also consistent with the differences in the dissolved $\mathrm{Mg}, \mathrm{Cl}, \mathrm{dFe}$, $\mathrm{dMn}$, and $\mathrm{SO}_{4}{ }^{2-}$ concentrations of the vent fluids between the PACMANUS and Desmos fields [27, 43], in which the maximum $\mathrm{SO}_{4}{ }^{2-}$ concentration $(147 \mathrm{mmol} / \mathrm{kg}$; [31]) of the vent fluids was observed in the Desmos field and the maximum dFe $(13400 \mu \mathrm{mol} / \mathrm{kg})$ and $\mathrm{dMn}(4540 \mu \mathrm{mol} / \mathrm{kg})$ concentrations of the vent fluids were observed in the Fenway vent site of the PACMANUS field $([27,29,43]$; Tables 1 and 2). This showed that variations in the major components of anomalous layers in the seawater columns in the Manus Basin are controlled by chemical variations in the intensity and position of the sources of the vent fluids [27, 43]. All these findings suggest that the fluid sources of hydrothermal plumes in the PACMANUS field have the characteristics of higher dissolved $\mathrm{Cl}, \mathrm{dFe}$, and $\mathrm{dMn}$ and lower $\mathrm{SO}_{4}{ }^{2-}$ abundance compared with those of the Desmos field and imply that the difference in the plume chemistry may reflect the differences in the vent fluid chemistry.

5.3. Dispersion of Hydrothermal Plumes. The physical and chemical properties of seawater columns in the Manus Basin are affected by the input of high-Mn, high-Fe, and low-Mg vent fluids. The turbidity (up to 0.484 FTU and $0.292 \mathrm{FTU}$ ), $\mathrm{dFe}$ (up to $0.133 \mu \mathrm{mol} / \mathrm{kg}$ and $0.084 \mu \mathrm{mol} / \mathrm{kg}$ ), and $\mathrm{dMn}$ (up to $0.539 \mu \mathrm{mol} / \mathrm{kg}$ and $0.158 \mu \mathrm{mol} / \mathrm{kg}$ ) concentrations in the hydrothermal plumes near the Satanic Mills (P-W02), Fenway (P-W04), and Desmos (D-W01 and D-W04) vent sites were generally higher than those of the P-W07 and D-W09 plumes, while the dissolved $\mathrm{Mg}$ concentration $(49.5 \mathrm{mmol} / \mathrm{kg}$ and $49.4 \mathrm{mmol} / \mathrm{kg}$ ) was generally lower than those of the P-W07 and D-W09 plumes far from the vent sites in the PACMANUS and Desmos fields (Tables 1 and 2), thereby implying that the P-W04, P-W02, D-W01, and D-W04 plumes are located near their vent fluid sources and are relatively young and the P-W07 and D-W09 plumes are located far from fluid sources and are older (Figures 1(c) and 1(d)). These patterns were also consistent with the differences in the $\mathrm{dMn}$ and $\mathrm{dFe}$ concentrations of the vent fluids between the PACMANUS $(1840-4221 \mu \mathrm{mol} / \mathrm{kg}$ of $\mathrm{Mn} ; 648.8-6468 \mu \mathrm{mol} / \mathrm{kg}$ of Fe) and Desmos (Mn $40-110 \mu \mathrm{mol} / \mathrm{kg}$ of Mn; $10-12400 \mu \mathrm{mol} / \mathrm{kg}$ of Fe) fields ([27, 43]; Tables 1 and 2), thereby implying that the high-Mn content in the vent fluids and the low bottom current velocity led to the higher Mn concentration in the plume than that in the ambient seawater even after dilution. However, the maximum dMn concentration (approximately
$110 \mathrm{nmol} / \mathrm{kg}$ ) of the Desmos hydrothermal plume was lower than that of the PACMANUS plume, which was caused by the high-temperature (up to $358^{\circ} \mathrm{C}$ ) hydrothermal activity that discharges mostly Mn-rich fluids and the lower bottom current $(<0.18 \mathrm{~m} / \mathrm{s})$ in the PACMANUS field (Figure 4) $[28,31,36]$, and higher than that $(18.2-45.5 \mathrm{nmol} / \mathrm{kg})$ of the Lau Basin [22].

However, the turbidity contour maps revealed two distinct anomaly centers corresponding to the Satanic Mills site (P-W02) and Fenway site (P-W04), and the two plumes intersected with each other at a depth of $1625 \mathrm{~m}$ to $1550 \mathrm{~m}$ (Figures 4(a)-4(d)). At a depth of $1625 \mathrm{~m}$ and $1620 \mathrm{~m}$, the mixed plume showed a southeastward dispersion trend controlled primarily by the current at P-W01, and the current velocities of the Satanic Mills plume and Fenway plume were too low to affect the dispersion (Figures 4(a), 4(b), and 4(f)). At a depth of $1605 \mathrm{~m}$, the Satanic Mills plume was affected by a significant northwestward current, which caused the mixed plume to extend along the northwest direction (Figures 4(c) and $4(\mathrm{f})$ ). At a depth of $1550 \mathrm{~m}$, the southeastward current at P-W07 obstructed the northwestward dispersion of the Satanic Mills plume (Figures 4(d) and 4(f)). At a depth of $1525 \mathrm{~m}$, the Satanic Mills plume disappeared and the Fenway plume seemed to be influenced by a nearby southeastward current (Figure 4(e)).

The turbidity anomalies observed at P-W01, which is located between P-W02 and P-W04, were the result of the intersection of the Satanic Mills plume and Fenway plume at $1625 \mathrm{~m}, 1620 \mathrm{~m}$, and $1605 \mathrm{~m}$. At a depth of $1625 \mathrm{~m}$, approximately $31 \%$ of the Satanic Mills plume intersected with $69 \%$ of the Fenway plume according to the turbidity of these plumes (0.329 NTU at P-W02, 0.254 NTU at PW01, and $0.220 \mathrm{NTU}$ at P-W04). At a depth of $1620 \mathrm{~m}$, approximately $78 \%$ of the Satanic Mills plume intersected with $22 \%$ of the Fenway plume (0.326 NTU at P-W02, $0.300 \mathrm{NTU}$ at P-W01, and $0.208 \mathrm{NTU}$ at P-W04), and at a depth of $1605 \mathrm{~m}$, approximately $0.7 \%$ of the Satanic Mills plume intersected with $99.3 \%$ of the Fenway plume $(0.365$ NTU at P-W02, 0.339 NTU at P-W01, and 0.337 NTU at P-W04). The contribution of the Fenway plume to the turbidity at P-W01 decreased from $1625 \mathrm{~m}$ to $1620 \mathrm{~m}$ and then increased, which was consistent with the turbidity variation of the Fenway plume, thereby suggesting that the influences on the turbidity at P-W01 by the Fenway plume were more notable than those by the Satanic Mills plume. This might have been due to the shorter distance between P-W01 and the Fenway plume than that between P-W01 and the Satanic Mills plume.

\section{Conclusions}

The hydrothermal plumes were distinguished by higher turbidity and $\mathrm{dFe}$ and $\mathrm{dMn}$ concentrations in the seawater columns, a rise of approximately $140-220 \mathrm{~m}$, and lateral dispersal of hundreds of meters in the PACMANUS and Desmos hydrothermal fields. The Satanic Mills plume and Fenway plume were identified at a depth between $1625 \mathrm{~m}$ and $1525 \mathrm{~m}$ with maximum dMn concentrations of $0.533 \mu \mathrm{mol} / \mathrm{kg}$ and $0.539 \mu \mathrm{mol} / \mathrm{kg}$ and maximum $\mathrm{dFe}$ 
concentrations of $0.058 \mu \mathrm{mol} / \mathrm{kg}$ and $0.133 \mu \mathrm{mol} / \mathrm{kg}$, respectively. Although the dilution of $\mathrm{dFe}$ was one order of magnitude greater than that of $\mathrm{dMn}, \mathrm{dFe}$ was removed more slowly than dMn during the lateral plume dispersal. The Satanic Mills plume and Fenway plume intersected with each other at a depth deeper than $1550 \mathrm{~m}$, and the direction of dispersion of the mixed plume was affected by the nearby current.

Turbidity, $\mathrm{dFe}$, and $\mathrm{dMn}$ anomalies higher than those in the other layers were observed in the seawater columns of the PACMANUS and Desmos fields, all of which indicated high$\mathrm{Mn}$ and high-Fe fluid input. However, the turbidity and $\mathrm{dFe}$ and $\mathrm{dMn}$ concentrations of the plumes in the PACMANUS field were higher than those in the Desmos plumes, thereby implying that the influence of the $\mathrm{Fe}$ and $\mathrm{Mn}$ concentrations in the vent fluids on the hydrothermal plumes in the PACMANUS field was stronger than that in the Desmos field.

Compared with those of hydrothermal plumes in the Desmos field, the vent fluid sources of plumes in the PACMANUS field had the characteristics of higher dissolved $\mathrm{Cl}$, $\mathrm{dFe}$, and $\mathrm{dMn}$ and lower $\mathrm{SO}_{4}{ }^{2-}$ abundance, and the plumes near the vent fluid sources were younger than those far from the fluid sources.

\section{Data Availability}

The underlying data related to our submission is available on request from zgzeng@ms.qdio.ac.cn.

\section{Additional Points}

Highlights. Dissolved Fe is removed more slowly than dissolved Mn during lateral plume dispersal. There is a clear visible intersection of plumes in the PACMANUS hydrothermal field. The influence of $\mathrm{Fe}$ and $\mathrm{Mn}$ in vent fluids on plume is weakened as the distance from the vent increased. Varied dispersion trends of the mixed plumes are affected by current velocities.

\section{Conflicts of Interest}

The authors declare that they have no conflicts of interest.

\section{Acknowledgments}

We would like to thank the crews on duty during the MANUS cruise in 2015 for helping us to collect the samples. This work was supported by the National Natural Science Foundation of China (Grant no. 91958213), the National Program on Global Change and Air-Sea Interaction (Grant no. GASI-GEOGE-02), the International Partnership Program of Chinese Academy of Sciences (Grant no. 133137KYSB20170003), the National Key Basic Research Program of China (Grant no. 2013CB429700), and the Special Fund for the Taishan Scholar Program of Shandong Province (Grant no. ts201511061).

\section{References}

[1] C. R. German and W. E. Seyfried Jr., "Hydrothermal Processes," in Treatise on Geochemistry, H. D. Holland and K. K. B. Turekian, Eds., pp. 191-233, Elsevier, Oxford, U.K., 2nd edition, 2014.

[2] J. C. Alt, "Subseafloor processes in mid-ocean ridge hydrothermal systems," in In Seafloor Hydrothermal Systems: Physical, Chemical, Biological, and Geological Interactions, S. E. Humphris, R. A. Zierenberg, L. S. Mullineaux, and R. E. Thomson, Eds., pp. 85-114, American Geophysical Union, Washington, D. C, 1995.

[3] D. A. Butterfield, W. E. Seyfried Jr., and M. D. Lilley, "Composition and evolution of hydrothermal fluids," in Energy and Mass Transfer in Marine Hydrothermal Systems, P. E. Halbach, V. Tunnicliffe, and J. R. Hein, Eds., pp. 123-161, Dahlem University Press, Berlin, 2003.

[4] K. L. Von Damm, "Controls on the chemistry and temporal variability of seafloor hydrothermal fluid," in Seafloor Hydrothermal Systems: Physical, Chemical, Biological, and Geological Interactions, S. E. Humphris, R. A. Zierenberg, L. S. Mullineaux, and R. E. Thomson, Eds., pp. 222-247, American Geophysical Union, Washington, D. C, 1995.

[5] J. M. Edmond, K. L. Von Damm, R. E. McDuff, and C. I. Measures, "Chemistry of hot springs on the East Pacific Rise and their effluent dispersal," Nature, vol. 297, no. 5863, pp. 187191, 1982.

[6] R. A. Feely, M. Lewison, G. J. Massoth et al., "Composition and dissolution of black smoker particulates from active vents on the Juan de Fuca ridge," Journal of Geophysical Research: Solid Earth, vol. 92, no. B11, pp. 11347-11363, 1987.

[7] R. A. Feely, E. T. Baker, K. Marumo et al., "Hydrothermal plume particles and dissolved phosphate over the superfastspreading southern East Pacific Rise," Geochimica et Cosmochimica Acta, vol. 60, no. 13, pp. 2297-2323, 1996.

[8] P. Jean-Baptiste, E. Fourré, J. L. Charlou, C. R. German, and J. Radford-Knoery, "Helium isotopes at the Rainbow hydrothermal site (Mid-Atlantic Ridge, $36^{\circ} 14^{\prime} \mathrm{N}$ )," Earth and Planetary Science Letters, vol. 221, no. 1-4, pp. 325-335, 2004.

[9] M. D. Lilley, R. A. Feely, and J. H. Trefry, "Chemical and biological transformations in hydrothermal plumes," in Seafloor Hydrothermal Systems: Physical, Chemical, Biological, and Geological Interactions, S. E. Humphris, R. A. Zierenberg, L. S. Mullineaux, and R. E. Thomson, Eds., pp. 369-391, American Geophysical Union, Washington, D. C, 1995.

[10] J. E. Lupton, E. T. Baker, N. Garfield et al., "Tracking the evolution of a hydrothermal event plume with a RAFOS neutrally buoyant drifter," Science, vol. 280, no. 5366, pp. 1052-1055, 1998.

[11] M. J. Mottl and T. F. McConachy, "Chemical processes in buoyant hydrothermal plumes on the East Pacific Rise near $21^{\circ} \mathrm{N}, "$ Geochimica et Cosmochimica Acta, vol. 54, no. 7, pp. 1911-1927, 1990.

[12] J. N. Fitzsimmons, S. G. John, C. M. Marsay et al., "Iron persistence in a distal hydrothermal plume supported by dissolvedparticulate exchange," Nature Geoscience, vol. 10, no. 3, pp. 195-201, 2017.

[13] G. Klinkhammer, P. Rona, M. Greaves, and H. Elderfield, "Hydrothermal manganese plumes in the Mid-Atlantic Ridge rift valley," Nature, vol. 314, no. 6013, pp. 727-731, 1985.

[14] M. D. Rudnicki and H. Elderfield, "A chemical model of the buoyant and neutrally buoyant plume above the TAG vent 
field, 26 degrees N, Mid-Atlantic Ridge," Geochimica et Cosmochimica Acta, vol. 57, no. 13, pp. 2939-2957, 1993.

[15] J. A. Resing, P. N. Sedwick, C. R. German et al., "Basin-scale transport of hydrothermal dissolved metals across the South Pacific Ocean," Nature, vol. 523, no. 7559, pp. 200-203, 2015.

[16] A. Gartman, A. J. Findlay, and G. W. Luther III, "Nanoparticulate pyrite and other nanoparticles are a widespread component of hydrothermal vent black smoker emissions," Chemical Geology, vol. 366, pp. 32-41, 2014.

[17] C. M. Sands, D. P. Connelly, P. J. Statham, and C. R. German, "Size fractionation of trace metals in the Edmond hydrothermal plume, Central Indian Ocean," Earth and Planetary Science Letters, vol. 319-320, pp. 15-22, 2012.

[18] M. Yücel, A. Gartman, C. S. Chan, and G. W. Luther III, "Hydrothermal vents as a kinetically stable source of ironsulphide-bearing nanoparticles to the ocean," Nature Geoscience, vol. 4, no. 6, pp. 367-371, 2011.

[19] S. A. Bennett, E. P. Achterberg, D. P. Connelly, P. J. Statham, G. R. Fones, and C. R. German, "The distribution and stabilisation of dissolved Fe in deep-sea hydrothermal plumes," Earth and Planetary Science Letters, vol. 270, no. 3-4, pp. 157-167, 2008.

[20] J. A. Hawkes, D. P. Connelly, M. Gledhill, and E. P. Achterberg, "The stabilisation and transportation of dissolved iron from high temperature hydrothermal vent systems," Earth and Planetary Science Letters, vol. 375, pp. 280-290, 2013.

[21] S. G. Sander and A. Koschinsky, "Metal flux from hydrothermal vents increased by organic complexation," Nature Geoscience, vol. 4, no. 3, pp. 145-150, 2011.

[22] A. P. Lisitzin, V. N. Lukashin, V. V. Gordeev, T. F. McConachy, S. D. Scott, and V. P. Shevchenko, "Hydrological and geochemical anomalies associated with hydrothermal activity in SW Pacific marginal and back-arc basins," Marine Geology, vol. 142, no. 1-4, pp. 7-45, 1997.

[23] T. Gamo, H. Sakai, J. Ishibashi et al., "Hydrothermal plumes in the eastern Manus Basin, Bismarck Sea: $\mathrm{CH}_{4}, \mathrm{Mn}, \mathrm{Al}$ and $\mathrm{pH}$ anomalies," Deep Sea Research Part I: Oceanographic Research Papers, vol. 40, no. 11-12, pp. 2335-2349, 1993.

[24] Z. Zeng, X. Wang, H. Qi, and B. Zhu, "Arsenic and antimony in hydrothermal plumes from the eastern Manus basin, Papua New Guinea," Geofluids, vol. 2018, Article ID 6079586, 13 pages, 2018.

[25] B. Taylor and F. Martinez, "Back-arc basin basalt systematics," Earth and Planetary Science Letters, vol. 210, no. 3-4, pp. 481497, 2003.

[26] R. A. Binns and S. D. Scott, "Actively forming polymetallic sulfide deposits associated with felsic volcanic rocks in the eastern Manus back-arc basin, Papua New Guinea," Economic Geology, vol. 88, no. 8, pp. 2226-2236, 1993.

[27] P. R. Craddock, W. Bach, J. S. Seewald, O. J. Rouxel, E. Reeves, and M. K. Tivey, "Rare earth element abundances in hydrothermal fluids from the Manus Basin, Papua New Guinea: Indicators of sub-seafloor hydrothermal processes in backarc basins," Geochimica et Cosmochimica Acta, vol. 74, no. 19, pp. 5494-5513, 2010.

[28] T. Gamo, K. Okamura, J. L. Charlou et al., "Acidic and sulfaterich hydrothermal fluids from the Manus back-arc basin, Papua New Guinea," Geology, vol. 25, no. 2, pp. 139-142, 1997.

[29] E. P. Reeves, J. S. Seewald, P. Saccocia et al., "Geochemistry of hydrothermal fluids from the PACMANUS, Northeast Pual and Vienna Woods hydrothermal fields, Manus Basin, Papua New Guinea," Geochimica et Cosmochimica Acta, vol. 75, no. 4, pp. 1088-1123, 2011.

[30] S. Roberts, W. Bach, R. A. Binns et al., "Contrasting evolution of hydrothermal fluids in the PACMANUS system, Manus Basin: the Sr and S isotope evidence," Geology, vol. 31, no. 9, pp. 805-808, 2003.

[31] J. S. Seewald, E. P. Reeves, W. Bach et al., "Submarine venting of magmatic volatiles in the eastern Manus Basin, Papua New Guinea," Geochimica et Cosmochimica Acta, vol. 163, pp. 178199, 2015.

[32] Z. Zeng, H. Ouyang, X. Yin, S. Chen, X. Wang, and L. Wu, "Formation of Fe-Si-Mn oxyhydroxides at the PACMANUS hydrothermal field, eastern Manus Basin: mineralogical and geochemical evidence," Journal of Asian Earth Sciences, vol. 60, pp. 130-146, 2012.

[33] J. M. McDermott, S. Ono, M. K. Tivey, J. S. Seewald, W. C. Shanks III, and A. R. Solow, "Identification of sulfur sources and isotopic equilibria in submarine hot- springs using multiple sulfur isotopes," Geochimica et Cosmochimica Acta, vol. 160, pp. 169-187, 2015.

[34] J. Thal, M. Tivey, D. Yoerger, N. Jöns, and W. Bach, “Geologic setting of PACManus hydrothermal area - High resolution mapping and in situ observations," Marine Geology, vol. 355, pp. 98-114, 2014.

[35] S. H. Park, S. M. Lee, G. D. Kamenov, S. T. Kwon, and K. Y. Lee, "Tracing the origin of subduction components beneath the South East Rift in the Manus Basin, Papua New Guinea," Chemical Geology, vol. 269, no. 3-4, pp. 339-349, 2010.

[36] K. R. Gena, H. Chiba, T. Mizuta, and O. Matsubaya, "Hydrogen, oxygen and sulfur isotope studies of seafloor hydrothermal system at the Desmos caldera, Manus backarc basin, Papua New Guinea: an analogue of terrestrial acid hot crater-lake," Resource Geology, vol. 56, no. 2, pp. 183-190, 2006.

[37] K. Gena, T. Mizuta, D. Ishiyama, and T. Urabe, “Acid-sulphate type alteration and mineralization in the DESMOS caldera, Manus back-arc basin, Papua New Guinea," Resource Geology, vol. 51, no. 1, pp. 31-44, 2001.

[38] Z. Zeng, X. Wang, C. T. A. Chen, and H. Qi, “Understanding the compositional variability of the major components of hydrothermal plumes in the Okinawa Trough," Geofluids, vol. 2018, Article ID 1536352, 20 pages, 2018.

[39] G. Cutter, P. Andersson, L. Codispoti et al., Sampling and sample-handling protocols for GEOTRACES cruises, AWI Organizations, 2010.

[40] I. Rodushkin and T. Ruth, "Determination of trace metals in estuarine and seawater reference materials by high resolution inductively coupled plasma mass spectrometry," Journal of Analytical Atomic Spectrometry, vol. 12, no. 10, pp. 11811185, 1997.

[41] M. P. Field and R. M. Sherrell, "Dissolved and particulate Fe in a hydrothermal plume at $9^{\circ} 45^{\prime} \mathrm{N}$, East Pacific Rise: Slow Fe (II) oxidation kinetics in Pacific plumes," Geochimica et Cosmochimica Acta, vol. 64, no. 4, pp. 619-628, 2000.

[42] H. Wang, Q. Yang, F. Ji, M. D. Lilley, and H. Zhou, "The geochemical characteristics and $\mathrm{Fe}(\mathrm{II})$ oxidation kinetics of hydrothermal plumes at the Southwest Indian Ridge," Marine Chemistry, vol. 134-135, pp. 29-35, 2012.

[43] W. Bach, S. Roberts, D. A. Vanko et al., "Controls of fluid chemistry and complexation on rare-earth element contents 
of anhydrite from the PACMANUS subseafloor hydrothermal system, Manus Basin, Papua New Guinea," Mineralium Deposita, vol. 38, no. 8, pp. 916-935, 2003.

[44] X. Ma, J. Yan, Z. Luan, X. Zhang, C. E. Zheng, and D. Sun, "High-resolution topography measurement of PACMANUS and DESMOS hydrothermal fields using a ROV in Manus basin," Scientific Bulletin, vol. 61, no. 15, pp. 1154-1156, 2016.

[45] E. Douville, P. Bienvenu, J. L. Charlou et al., "Yttrium and rare earth elements in fluids from various deep-sea hydrothermal systems," Geochimica et Cosmochimica Acta, vol. 63, no. 5, pp. 627-643, 1999. 